\title{
RIGHTS OF THE CRIMINALLY ACCUSED
}

\author{
B.J. GEORGE, JR.* \\ I \\ INTRODUCTION
}

The Japanese criminal justice system provides the criminally accused an impressive set of legal protections. Although these protections came fully into being only with the adoption of the 1947 Constitution and are, in great measure, of continental and Anglo-American origin, they are highly developed and safeguard the human rights of an accused at all stages of a criminal proceeding. This article provides a comprehensive overview of the protections afforded accused persons under Japanese law. It first explores the historical sources of the safeguards built into modern Japanese criminal law and procedure; next discusses the general treatment of rights and the structure of the criminal justice system under the Japanese Constitution; and, finally, addresses in detail both the substantive and procedural protections available to accused persons under the Japanese Constitution and the Code of Criminal Procedure.

\section{II}

The Historical Background

\section{A. Roots of the Present System}

In contrast to the history of Western nations, including the United States, in which the roots of diverse protections for the human rights of criminal suspects and defendants lie generations or centuries in the past, the formal recognition in Japan of a concept of "rights" for accused persons is almost exclusively a consequence of the adoption of the present Shōwa Constitution of 1947. Moreover, a structure of formal criminal proceedings in Japan was initiated only in $1882 . .^{1}$ For that reason, to survey the current scope of the protections afforded criminal suspects and defendants in Japan is to inquire into a highly contemporary hybrid system of American concepts engrafted

Copyright $(\mathcal{O} 1990$ by Law and Contemporary Problems

* Professor, New York Law School; honorary member, Nihon Keihō Gakkai (Japan Criminal Law Society).

1. The Code of Criminal Instruction (Chizai hö) of 1880 took effect concurrently with the old Penal Code on January 1, 1882. See generally S. Dando, Japanese Law of Criminal Procedure 15-16 (B. George trans. 1965); R. IshiI, Japanese Legislation in the Meiji Era 512-24 (W. Chambliss trans. 1958); Takayanagi, A Century of Innovation: The Development of Japanese Law, 1868-1961, in LAw in Japan: The Legal Order in a Changing Society 5, 18-19 (A. von Mehren ed. 1963) [hereinafter LAW IN JAPAN]. 
onto a root stock heavily influenced by late nineteenth- and early twentiethcentury Continental European legal doctrines.

\section{B. The Feudal Era}

The earliest codifications of law in Japan, the Code of 702 (Taiho) and the Code of 718 (Yo-ro), were heavily influenced by the slightly earlier Sui and T'ang Codes of China. ${ }^{2}$ Charges were instituted by government officials; adjudications had to be based on either defendants' confessions or the testimony of witnesses; ${ }^{3}$ and appeals could be lodged against convictions. However, as the imported code systems disintegrated in the succeeding feudal eras of Kamakura ${ }^{4}$ and Muromachi (Ashikaga), ${ }^{5}$ the vestiges of the earlier imported codes disappeared. Norms of conduct were disseminated in the form of administrative criminal regulations enforced by bakufu officials either locally or centrally. ${ }^{6}$

After the succession to bakufu control by Tokugawa Ieyasu ${ }^{7}$ and the subsequent consolidation of effective Tokugawa clan hegemony over the entire nation, ${ }^{8}$ the administrative-criminal process instituted in earlier eras continued unchanged. ${ }^{9}$ The norms to guide various bodies of people were usually couched in general terms as moral rules and precepts. Because these precepts were known and accepted by most persons, it was considered unnecessary to promulgate specific explanations of the methods by which they were to be enforced. Consequently, the emphasis in the criminal regulations of the last century of the Tokugawa shogunate, ${ }^{10}$ which were internal documents for official guidance not disseminated to the populace, was on such matters as methods to be taken to discover the truth from offenders' lips and to execute condemned criminals. ${ }^{11}$

\section{The Meiji Period}

With the termination of the Tokugawa shogunal control of the Japanese government and the restoration of power to the emperor, ${ }^{12}$ Japan embarked on a rapid modernization of its political, economic, and legal apparatus.

2. See S. Dando, supra note 1 , at 12-13; 1 G. Sansom, A History of Japan to 1334 , at $67-70$ (1963).

3. See S. DANDo, supra note 1, at 13. If the evidence were evenly balanced concerning the truth of the charges, a duty of compensation could be imposed based on suspicion only.

4. The feudal era of Kamakura was from 1185 to 1392 . See generally $1 \mathrm{G}$. Sansom, supra note 2, at 345-58.

5. The feudal era of Muromachi was from 1392 to 1573. See generally 2 G. Sansom, A History OF JAPAN 1334-1615, 143-48, 300-02 (1963)

6. See S. Dando, supra note 1, at 13-14.

7. Tokugawa Ieyasu's succession followed his brilliant suppression of contending feudal clan leaders at the battle of Sekigahara in 1600. See 2 G. Sansom, supra note 5, at 385-406.

8. See generally 3 G. SANSOM, A History OF JAPAN 1615-1867 (1963).

9. See Henderson, Some Aspects of Tokugawa Law, 27 WASh. L. REv. 85, 89-90 (1952).

10. In particular, O-Sadame-Gaki (1742), including the Code of 100 Articles (Hyakkajō). See Henderson, supra note 9 , at 90 ; Takayanagi, supra note 1 , at 16 .

11. See Henderson, supra note 9 , at 108 .

12. See generally W. Beasley, Modern History of Japan 76-116 (3d ed. 1982); C. Totman, Collapse of the Tokugawa Bakufu, 1862-1868 (1980). 
Perhaps the strongest objective for the reform of the legal apparatus was to provide a basis to negotiate away the treaties with Western powers, including the treaty with the United States, that provided extraterritorial protections for westerners in Japan. ${ }^{13}$ As part of the process, a criminal procedure code and a penal code were adopted, 14 both of which substantially resembled the French codes of the time. ${ }^{15}$

However, far more significant in the development of the concept of human rights within the criminal process was the emperor's promulgation of a constitution in 1889.16 That document, however, was based on the Prussian pattern ${ }^{17}$ and not on the pattern presupposed as standard in the United States. Consequently, the constitution was in the nature of a "fundamental law of State" by which the emperor exhibited the principles that would guide imperial conduct. ${ }^{18}$ Under Chapter II, headed "Rights and Duties of Subjects," 19 only four areas were addressed relating to the administration of criminal justice: (1) arrest, detention, trial, or punishment had to be "according to law;"20 (2) trial had to be conducted by judges, as determined by law; ${ }^{21}$ (3) the houses of Japanese subjects could not be entered or searched without consent "except in cases provided for by law";22 and (4) secrecy of correspondence was to remain inviolate "except in instances mentioned in the law."23 Because, as matters of both theory and form, the emperor had to approve the promulgation of statutes through an imperial edict, ${ }^{24}$ there was no basis whatever to view these or any other provisions of Chapter II as creating "rights that the people can claim as human beings"; they were only "rights of the subjects" given by the "will of the emperor." 25

13. See W. Beasley, supra note 12, at 159-60.

14. Between 1869 and January 1,1882 , there were several interim substantive and procedural enactments under which important steps were taken to adopt both penal norms and a criminal justice system that resembled those established in France. See generally S. Dando, supra note 1, at 14-16; R. IshiI, supra note 1, at 17, 333-42; Armstrong, A Perspective on Japanese Criminal Law and Procedure, 5 LaWASIA 179, 185-86 (1974); Henderson, supra note 9, at 88-90; Takayanagi, supra note 1, at 19-20; Wren, Legal System of Pre-Western Japan, 20 Hastings L.J. 217, 231 -32 (1968).

15. See G. Boissonade, Projet Revisé de Code Pénal pour l'Empire du Japon accompagné D'Un Commentaire (1886); R. Ishil, supra note 1, at 562-63; K. NaKamura, Formation of Japanese Law as Viewed from Legal History 73 (1962). Gustave Emile Boissonade de Fontarabie (18251910), a professor on the Faculty of Law at the University of Paris, served as an adviser to the Government of Japan on legal matters for over 20 years. See Y. NOdA, InTRoduction To JaPANESE LAw 45-48 (A. Angelo trans. 1976).

16. See generally R. Ishil, supra note 1 , at 366-81; N. Matsunami, Japanese Constitution and Politics 37-40 (1940); Takayanagi, supra note 1 , at 6-9.

17. See $\mathrm{R}$. Ishil, supra note 1 , at 366-67, 369; N. Matsunami, supra note 16, at 37-38; Armstrong, supra note 14 , at $184-85$.

18. Meıjı Const. preamble (Dai Nippon Teikoku Kempō). See also N. Matsunami, supra note 16, at 53-56 (imperial speech upon the promulgation of the constitution).

19. Meiji Const. ch. II.

20. Id. art. 23.

21. Id. art. 24.

22. Id. art. 25.

23. Id. art. 26.

24. See S. FujiI, Essentials of Japanese Constitutional Law 332-34 (1940).

25. Miyasawa, Kempō Constitutional Law (1962), translated in H. Tanaka, Japanese Legal System: Introductory Cases and Materials 630, 637 (1976) (emphasis in original). Statutes, in theory, could never be contrary to the constitution, see S. FujII, supra note 24 , at 334 , but there were no 


\section{The Contemporary Constitutional Setting}

The adoption of the 1947 Shōwa Constitution signaled, of course, a revolution in the assumptions on which Japanese constitutional law rested and the establishment both of constitutional or human rights and of a mechanism to enforce them. Although in form an amended version of the Meiji Constitution, ${ }^{26}$ the Shōwa Constitution rather clearly was a new document substantially influenced by pressure from the Supreme Commander Allied Powers ("SCAP") for basic changes in the structure of government polity and law. ${ }^{27}$ Through its adoption, Japan entered an era in which human rights, including those of suspects and accused persons, became a viable, enforceable concept.

\section{III}

\section{The Constitutional Construct for Rights of Accused Persons}

\section{A. The Constitutional Status of Rights}

As noted, ${ }^{28}$ the Meiji Constitution granted nothing that could be viewed as "rights"; not only were the purported rights all qualified by phrases like "except as provided by law," but the term "right" itself was alien to the traditional Japanese ethos. ${ }^{29}$ Hence, only the coverage of "duties" was consistent with traditional Japanese values. The present Constitution continues the chapter heading of "Rights and Duties of the People,"30 perhaps in large measure because in form it is an amended version of the Meiji Constitution. ${ }^{31}$ However, the duties that the Constitution imposes are highly restricted, ${ }^{32}$ and the rights it confers are to remain untrammelled by

specific, unqualified provisions affecting penal law and procedure, so the reservation was meaningless; in any event, there was no mechanism to invalidate legislation on constitutional grounds, id.; but see id. at 315-16 (proper not to apply a law found to be in conflict with the constitution). See also N. Matsunami, supra note 16, at 226-27.

26. The instrument of promulgation by the Emperor on November 3, 1946, made express reference to Article 73(1) of the Meiji Constitution, which provided for the submission of a project for amendment to the Imperial Diet by Imperial Order.

27. Among the many resources addressing the processes leading to the promulgation of the present constitution, see Comm'n on the Constitution: The Final Report of the Commission on The Constitution 62-86 (J. Maki trans. 1980) [hereinafter Commission]; A. Oppler, Legal Reform In Occupied JAPAN 43-64 (1976); H. TANAKA, supra note 25, at 653-64; Armstrong, supra note 14, at 188-89; Ward, Origins of the Present Japanese Constitution, 50 Am. Pol. SCI. Rev. 980-82, 996-99, 1008-10 (1956).

28. See supra notes $19-25$ and accompanying text.

29. See, e.g., Y. NodA, supra note 15, at 44, 159-60; Beer \& Weeramantry, Human Rights in Japan: Some Protections and Problems, 1 Universal Hum. RTs., July-Sept. 1979, at 1, 3-5; Takayanagi, supra note 1 , at 24.

30. 1947 Const. ch. III (arts. 10-40).

31. See supra notes $26-27$ and accompanying text.

32. Four duties are imposed on the Japanese people: (1) spouses are to maintain marriage through mutual cooperation with the equal rights of husband and wife as a basis, 1947 CoNST. art. $24(2) ;(2)$ those with minor children under their protection are obliged to see that they receive a measure of ("ordinary") education fixed by law, id. art. 26(2); (3) all people have an obligation as well as a right to work, id. art. 27(1); and (4) children cannot be exploited by anyone, id. art. 27(3). People are also made liable to taxation as provided by law, id. art. 30 , an obligation qualitatively different 
legislation or other governmental action. ${ }^{33}$ Although during the first two decades of Japan's postwar constitutional regime there were minority rumblings that more attention should be given to an expanded list of enforceable constitutional duties imposed on the people, ${ }^{34}$ at present there appears to be no mainstream support for major revisions of the Chapter to limit or qualify rights and impose enforceable duties on the people. Accordingly, an evaluation of the contemporary constitutional and statutory rights of suspects and accused persons under the Japanese system uses a methodology familiar to the legal profession of the United States.

\section{B. The Structure for Enforcement of Rights}

Although fairly elaborate administrative procedures are in place to protect the constitutional rights of the Japanese people, ${ }^{35}$ the enforcement of substantive and procedural rights in the course of criminal proceedings is almost exclusively the responsibility of the courts through which criminal cases move. Although the matter is covered in much greater detail elsewhere in this symposium, ${ }^{36}$ it seems useful to stress the organic changes the

from the preceding list and continued from the Meiji Constitution. See H. Ito, Commentaries on the Constitution of the Empire of Japan 45-48 (1906); N. Matsunami, supra note 16, at 262-65. Finally, there is a general exhortation that the people are to refrain from abusing the rights conferred on them by the Constitution and are responsible for using them for the public welfare. 1947 CoNST. art. 12.

33. 1947 Const. art. 11 ("[T]he people shall not be prevented from enjoying any of the fundamental human rights [which] shall be conferred upon the people of this and future generations as eternal and inviolate rights.").

34. See Commission, supra note 27 , at $280-81$. It was also suggested, from a different perspective, that old concepts of "rights and duties" should be replaced by a label of "welfare and obligations of the people." Id at 385. The Commission thought it preferable, however, to emphasize Article 25 of the 1947 Constitution, which relates to the right of people "to maintain minimum standards of wholesome and cultured living," and to the duty of the state in all aspects of life to "use its endeavors for the promotion and extension of social welfare and security, and of public health," rather "than to strengthen limitations on the rights and freedoms of the people in the name of the principles of the contemporary welfare state." Id.

35. See generally Japan Ministry of Justice, Civil Liberties in Japan (undated); Beer \& Weeramantry, supra note 29, at 6-13; Rosch, Institutionalizing Mediation: The Evolution of the Civil Liberties Bureau in Japan, 21 LAw \& Soc'y Rev. 243 (1987).

36. See Itoh, Judicial Review and Judicial Activism in Japan, LAw \& ConTEMP. Probs., Winter 1990, at 169; Luney, The Judiciary: Its Organization and Status in the Parliamentary System, LAw \& ConTEMP. Probs., Winter 1990, at 135.

One might note that Article 40 of the 1947 Constitution guarantees a right to persons arrested or detained for a crime to sue the government for redress, under procedures established by law, following acquittal. That practice was first implemented by the Keiji hoshō hō (Criminal Compensation Law), Law No. 1, 1950, supplemented by the Keiji hoshōhō kisoku (Rules Governing Criminal Compensation) (Sup. Ct. Rule No. 1, 1950). See generally S. Dando, supra note 1, at 527-34. A limited measure of compensation is available through administrative action to persons against whom prosecution has not been instituted following arrest or detention. See George, Discretionary Authonity of Public Proseculors in Japan, in LAW AND SOCIETY IN CONTEMPORARY JAPAN: AMERICAN Perspectives 263, 271-72 (J. Haley ed. 1988).

A more substantial legislative step was taken by Law No. 23, 1976 in Articles 188-2 to 188-6 of the new Keisohō (Code of Criminal Procedure) to compensate acquitted accused persons for certain costs. These persons are compensated for adjudication costs, other than those which the accused person caused to arise, provided the prosecution did not result from false confessions or other evidence provided by the accused during the investigative phase. Id. arts. 188-2(1), (2). Those seeking indemnification must submit an application to the court that rendered the adjudication of 
Constitution made in the relationships between judges, public procurators, and defense counsel. In the author's view, these changes have made it possible to protect human rights effectively within the context of criminal justice administration.

Under the system in force through 1946, both judges and procurators were professional staff members of the Ministry of Justice and could be shifted through administrative action from one responsibility to another. ${ }^{37}$ During the procedural phase of preliminary inquiry (yoshin), the public procurator, sitting with the inquiring (examining) judge, examined the suspect and any other witnesses ${ }^{38}$ and compiled a dossier that would be transmitted to the court if a decision to institute formal prosecution were reached. ${ }^{39}$ Trial consisted exclusively of a hearing on the charges confirmed by a public procurator, an examination of the accused in the absence of other witnesses, a reading of the protocols, ${ }^{40}$ and the taking of testimony of witnesses and expert witnesses whose statements were not embodied in a protocol reflecting the preliminary inquiry. ${ }^{41}$ No right of representation by counsel arose until a "suspect" had become an "accused person," which meant that counsel's role was limited to impeaching the data reviewed by the court during public trial proceedings and to making closing submissions concerning guilt and sanctions. ${ }^{42}$ Thus, schematically speaking, the system before 1946 could be represented by an unstable inverted triangle, formed at the top by judges and public procurators on an equal level, with counsel for the accused in an inferior position.

not guilty within six months after that adjudication was entered. Id. arts. 188-3(1), (2). Indemnification for appellate costs is available only if the public prosecutor lodged an appeal and the appeal is thereafter either dismissed or withdrawn. Id arts. 188-4 through 188-5. The basic obligation of reimbursement extends to (a) travel expenses, per diem, and lodging expenses for the accused or for defense counsel for the accused, relating to appearances in court either in preparation for trial or on days of public trial, and (b) fees paid to defense counsel and witnesses. Id. art. 188 6(1). If there are multiple defense counsel, reimbursement of actual expenses may be limited to the chief defense counsel or some but not all counsel. Id. art. 188-6(2). The basic pattern of compensation is that provided by the Criminal Compensation Law.

37. See H. Quigley, Japanese Government and Politics 275, 276-77 (1932).

38. See J. DE Becker, Elements of Japanese Law 402-08 (1916) (Although this book describes the proceedings under the Code of Criminal Instruction of 1882 , a substantially equivalent relationship existed between judges and public procurators under the Code of Criminal Procedure of 1927.); R. IsHII, supra note 1 , at 525-28.

39. See J. DE BECKER, supra note 38, at 409. A key change in the present Code of Criminal Procedure, art. 256(6), forbids the annexation of or reference to any evidentiary document or other matter in an accusatory instrument (kisojō). See S. DANDo, supra note 1 , at 346-47. The provision clearly attests to the markedly altered relationship between judges and public prosecutors under the present system. See infra notes $43-46$ and accompanying text.

40. Under the current system, as well as the earlier one, the protocol is a special form of procedural document in which occurrences in judicial proceedings are preserved for later use. It is not, however, a "transcript" as the latter term is used in American practice. See S. Dando, supra note 1 , at 381-82 (citing CODE and RULE provisions).

41. See J. DE BECKER, supra note 38, at 409-10; Takayanagi, supra note 1, at 20-21.

42. Under both the former and present procedural systems (which are typical for Roman lawbased systems), a judgment of guilt covers both the legal conclusion of guilt and the sanctions to be imposed, suspended, or remitted. See Code of Crim. P. arts. 333-34; S. Dando, supra note 1, at 38586. 
Under the Shōwa Constitution, the triangle has flipped. The judiciary, with the Supreme Court at the apex ${ }^{43}$ has become an independent organ of government coordinate with the Diet. At the same time, the functions allocated to defense counsel under the adversarial criminal procedure established under the postwar Code of Criminal Procedure ("Code") have brought the private bar into a formal state of equality ${ }^{44}$ with public prosecutors, who continue to function within the Ministry of Justice. ${ }^{45}$ Accordingly, the system now forms a stable triangle, with the judiciary at the apex and public prosecutors and defense counsel on a coordinate level at its base. ${ }^{46}$ This systemic change toward an Anglo-American pattern has been both symbolically and functionally significant in safeguarding the constitutional and statutory rights of suspects and accused persons, as the following summary of those rights should confirm.

\section{IV}

\section{Constitutional Rights: Substantive Penal Law}

Although the bulk of constitutional attention is devoted to procedural matters, there are nonetheless certain constitutional doctrines that bear on the validity of substantive penal law and not on the procedures through which that penal law is enforced. Both substantive and procedural provisions, however, concur to protect the criminally accused.

\section{A. Article 31 Limitations}

Article 31 of the Constitution provides that "no person shall be deprived of life or liberty, nor shall any other criminal penalty be imposed, except according to procedure established by law." On its face, the provision seems not to reflect any greater concern than that penal legislation be enforced through procedures that conform to the Code and other laws and orders of procedural significance, and thus should not be taken as the equivalent to the due process clauses of the United States Constitution. ${ }^{47}$ Nevertheless, the

43. 1947 Const. arts. 76, 79. See generally Dando, Role of the Supreme Court in the Administration of Criminal Justice in Japan, in Festschrift Für Dietrich ÖEHLER zUM 70. Geburtstag 635, 635-40 (R. Herzberg ed. 1984); George, Japanese Judicial System: Thirty Years of Transition, 12 LoY. L.A.L. REV. 807, 813-16 (1979).

44. See generally S. Dando, supra note 1 , at 103-05, 107-10; H. Tanaka, supra note 25, at 533; Armstrong, supra note 14, at 200-02; Hattori, The Legal Profession in Japan: Its Historical Development and Present State, in LaW IN JaPAN, supra note 1 , at $111,136-38$.

45. See generally George, supra note 36 , at 264.

46. Nevertheless, in the actual conduct of criminal investigations and the prosecution's initial evaluation of criminal charges, as well as in the phase of precharging judicial activity, a lineal structure is perhaps more helpful to understanding the system. This is because the police are formally phased out, and courts and counsel for the accused are phased in when, but only when, the public prosecutorial apparatus decides to file an accusatory instrument. See supra note 39 . See generally George, supra note 36 , at 263, 267-68.

47. U.S. Const. amends. V, XIV, § 1. See Commission, supra note 27, at 280 (summarizing opinion that language should be amended to "procedures of just and proper law" to clarify that substantive as well as procedural conditions should be determined by law); H. TANAKA, supra note 25 , at 829 (indicating belief of many lawyers that Article 31 is equivalent to a due process clause because 
provision has become the basis for certain restrictions on the legislative process that are independent of criminal procedure.

One restriction is that the legality principle, that is, the principle of nullum crimen sine lege ${ }^{48}$ governs in Japan as a matter of constitutional law and criminal norms must be established by statutes enacted by the Diet. Hence, in contrast to the legal structure during the Meiji period when administrative orders could provide for the imposition of criminal punishments, ${ }^{49}$ Cabinet orders cannot include penal provisions unless legislation expressly authorizes them. ${ }^{50}$ Article 31 has been invoked to challenge statutes and local ordinances as vague and indefinite, although to date the Supreme Court of Japan has not invalidated any of the provisions under attack. ${ }^{51}$

The companion norm of nulla poena sine lege likewise is incorporated in Article 31 , so that the scope and character of penalties for proscribed conduct must be delineated through legislation. ${ }^{52} \mathrm{~A}$ corollary is that punishments must be just and commensurate with the harm addressed by a penal statute. At least in terms of scholarly opinion, ${ }^{53}$ this provision goes beyond the prohibition against the infliction of "cruel punishments" 54 and builds into Article 31 the dimension of proportionality that constitutes, in the United States, one element of the constitutional prohibition against "cruel and unusual punishment." 55

of its SCAP inception, but noting an Indian Supreme Court construction of identical language as meaning "procedure established by a statute," Gopalan v. State of Madras, 37 A.I.R. 27 (Sup. Ct. 1950)); Dando, Basic Concepts in and Temporal and Territorial Limits on the Applicability of the Penal Law of Japan, 9 N.Y.L. Sch. J. INT'L \& Comp. L. 237, 242-43 (1988) (Article 31 should be viewed as equivalent to due process, embracing both a requirement that statutes be sufficiently precise to afford notice and a requirement of precise penalty limits).

48. See generally J. Hall, Law, Social. Science and Criminal Theory 105-06 (1982).

49. The Meiji Constitution provided generally in Article 9 that the emperor issues or causes to be issued ordinances, inter alia, for the maintenance of the public peace and order, and in Article 23 that Japanese subjects could be arrested, detained, tried, or punished only "according to law." The Law Concerning the Punishment of Violations of the Provisions of Administrative Orders, Law No. 84, 1890, generally authorized criminal penalties of fines not to exceed 200 yen or penal detention not to exceed one year. Under the Police Infraction Order, Ministry of Justice Order No. 16, 1909, a large number of penal regulations were issued on the strength of the 1890 law. See Dando, supra note 47 , at 238 .

50. 1947 Const. art. 73(6). See generally Dando, supra note 47, at 238. As Professor Dando notes, customary law can be used solely as a source of data bearing on the interpretation of statutory language and not as an independent source of penal norms. Id. at 239. Precedent, at least from the standpoint of scholarly analysis in Japan, only interprets a statutory text and does not create a penal norm independent of legislation. Id. at 240.

51. See Dando, supra note 47, at 241 n.6 (citing and summarizing Supreme Court precedent). Compare counterpart precedents of the United States Supreme Court. E.g., Boos v. Berry, 484 U.S. 808 (1987); Kolendar v. Lawson, 461 U.S. 352 (1983); Village of Hoffman Estates v. Flipside, Hoffman Estates, Inc., 455 U.S. 489 (1982).

52. See Dando, supra note 47 , at $240-41$.

53. See id. at $242-43$

54. 1947 Const. art. 36.

55. U.S. Const. amend. VIII. See Solem v. Helm, 463 U.S. 277 (1983); Rummel v. Estelle, 445 U.S. 263 (1980). 
One might also note that the Supreme Court of Japan ${ }^{56}$ invoked the constitutional provision guaranteeing the equality of all persons under the law and prohibiting discrimination in political, economic, or social relations because of race, creed, sex, social status, or family origin ${ }^{57}$ to invalidate the penalty provisions of the Penal Code that mandated more severe sanctions for killing a lineal ascendant ${ }^{58}$ than for other forms of homicide. ${ }^{59}$

\section{B. Prohibition Against Cruel Punishments}

As noted earlier, ${ }^{60}$ the Constitution of Japan expressly prohibits cruel punishments. The Supreme Court of Japan has ruled, however, that capital punishment, ${ }^{61}$-with hanging as the sole method of implementation authorized in the Penal Code ${ }^{62}$-and life imprisonment ${ }^{63}$ are not barred by the provisions of Article 36. The consensus appears to be that the abolition of the death penalty in Japan, if it comes, will be solely through a revision of the Penal Code, not judicial action. ${ }^{64}$

\section{Nonretroactivity Principle}

The principle forbidding the retroactive application of penal legislation may be viewed as a corollary to the nullum crimen and nulla poena principles discussed earlier. ${ }^{65}$ In contrast to the Meiji Constitution, which contained no express prohibition against retroactivity, 66 the present Constitution states expressly that no person can be adjudicated guilty for an act that was lawful at the time of its commission, ${ }^{67}$ a provision similar to, if not identical with, the ex post facto clauses of the United States Constitution. ${ }^{68}$ This provision would bar the retroactive application of harsher penalties even though the underlying criminal definition remains unchanged, but would guarantee no benefit to convicted persons if the penalties should be made less onerous than

56. Japan v. Nakamura, 16 Keishū 1593 (Sup. Ct., G.B., Nov. 28, 1962) (translated in H. ITOH \& L. Beer, Constitutional Case Law of Japan: Selected Supreme Court Decisions 1961-70, at 58 (1978)).

57. 1947 Const. art. 14(1).

58. Keishō (Penal Code) art. 200 (death or life imprisonment with forced labor).

59. Id. art. 199 (death or imprisonment with forced labor for life or a term not less than three years).

60. See supra note 54 and accompanying text.

61. See 1248 Hanrei Jihō 138 (Sup. Ct., 2d P.B., July 17, 1987); 1242 Hanrei Jihō 131 (Sup. Ct., 2d P.B., July 9, 1987). See generally S. Dando, Penal Law of Japan: General Part § $11.02(1)$ (B. George trans., in press).

62. Japan v. Ichikawa, 15 Keishù 1106 (Sup. Ct., G.B., July 19, 1961); Japan v. Hirazawa, 9 Keishū 663 (Sup. Ct., G.B., Dec. 21, 1949) (interpreting Penal Code art. 11(1)). See generally S. DANDo, supra note $61, \S 11.02(2)$.

63. Japan v. Kobayashi, 3 Keishū 2048 (Sup. Ct., G.B., Dec. 20, 1949); Japan v. Hiyoshi, 10 Keishū 1611 (Sup. Ct., 3rd P.B., Dec. 25, 1956).

64. See amnesty International, Death Penalty in Japan 16-18, 23-24 (1983); Commission, supra note 27 , at $282-83$.

65. See supra notes $48-55$ and accompanying text.

66. See Dando, supra note 47 , at 249 .

67. 1947 Const. art. 39.

68. U.S. Const. art. $1, \S 9 \mathrm{cl} .3, \S 10 \mathrm{cl}$. 1. See Miller v. Florida, 482 U.S. 423 (1987); Weaver v. Graham, 450 U.S. 24 (1981). 
they were at the time of the criminal act. The latter benefit, however, is provided for by the Penal Code, which states that "when a punishment is changed by law after the commission of a crime, the lesser punishment shall be applied." 69

V.

\section{Constitutional Rights: Criminal Procedure}

The bulk of the constitutional rights germane to this article relate to procedure. Moreover, the provisions of the Code must be examined closely in identifying the scope of protections afforded suspects and accused persons under law, for the Code was revised in 1948 to meet the mandates of the Constitution. A full exposition of Japanese criminal procedure far exceeds the allotted space for this article. Nevertheless, with the exceptions noted below, the protections delineated in the Code meet or exceed the minimum standards set by the Constitution, thus the majority of criminal appeals are resolved on the basis of code, not constitutional, interpretation.

\section{A. Criminal Investigation}

1. Arrest. Article 33 of the Constitution advances the basic premise that arrests should be based on a warrant issued by a competent judicial officer specifying the offense with which the person is charged. ${ }^{70}$ The constitutional provision contains one exception to that general requirement, however: Persons who are apprehended while committing an offense (genkōhan) are subject to immediate arrest without warrant. ${ }^{71}$ The Code defines persons who are committing or who have just committed offenses as flagrant offenders subject to arrest, ${ }^{72}$ but also treats by analogy certain classes of persons as flagrant offenders (jun-genkōhan): (1) persons being freshly pursued; (2) persons carrying criminally acquired matter, weapons, or other objects apparently used in connection with the offense; (3) persons bearing on their bodies or clothing visible traces of the offense; and (4) persons who flee when

69. Penal Code art. 6. See Dando, supra note 47, at 250-51.

70. The warrant must be issued before a person is apprehended and not afterwards. CODE OF CRIM. P. art. 199(1). If the predicate offense is minor, an arrest warrant may issue only if the person to be arrested has no fixed residence or has failed to appear without good reason before a public prosecutor, public prosecutor's assistant officer, or judicial police official when summoned under Code of Criminal Procedure Article 198. Id. See generally S. Dando, supra note 1, at 313.

The Supreme Court has not addressed the constitutionality of bekken taiho, an arrest for one crime under a warrant designed to ensure detention while another more serious crime is investigated. However, the Tokyo District Court ruled the practice an "evasion" of Articles 33 and 34 of the Constitution and thus unlawful. Japan v. Tsukamoto, 591 Hanrei Jihō 30 (Tokyo Dist. Ct., Feb. 26, 1970) (acquitting the accused). See also 37 Kokeishü 98 (Osaka H. Ct., Apr. 19, 1984), discussed in Cleary, Criminal Investigation in Japan, 26 CAL. W.L. REv. 123, 140-41 (1989) (concluding that if arrest is based on one crime but interrogation relates to another, the arrest is to be considered as if it were based on the latter).

71. 1947 Const. art. 33 proviso.

72. Code of Crim. P. art. 212(1). Any person, whether private citizen or public service employee, can execute such a flagrant offense arrest. Id. art. 213. See S. Dando, supra note 1, at 310; Cleary, supra note 70, at 138-40 (discussing Tokyo High Court precedent on duration of offense for purposes of flagrant delict arrest). 
challenged. ${ }^{73}$ Based on only a reading of the constitutional language, this code section might appear to stretch the wording of Article 33, but the provision appears to be almost universally accepted as valid. ${ }^{74}$

The Code ${ }^{75}$ also authorizes emergency arrests (kinkyū taiho) in cases involving serious offenses ${ }^{76}$ if exigent circumstances prevent the issuance of an arrest warrant in advance. Immediately after such arrests, however, steps must be taken to obtain a judicial arrest warrant; if none is issued, the suspect must be released from custody immediately. ${ }^{77}$ Although questions have been raised concerning the constitutionality of the provision under Article 33, it has been upheld by the Supreme Court. ${ }^{78}$

Neither the Constitution nor the Code directly addresses the question of the use of force in executing an arrest. ${ }^{79}$ However, under the Police Duties Law, ${ }^{80}$ police officers may display weapons when it appears reasonably necessary to apprehend a criminal, prevent the escape of an arrestee, protect the officer or a third person, or quell resistance to the execution of the officer's official duties. ${ }^{81}$ Injury can be inflicted through the use of a police weapon only when: (1) the case falls within the Penal Code provisions establishing the necessity defense ${ }^{82}$ or the defense of averting imminent danger; ${ }^{83}$ (2) a person subjected to a flagrant or quasi-flagrant delict arrest for an offense punishable by death or imprisonment for life or a term exceeding three years resists arrest or attempts to escape (or a third person intervenes for the purpose of enabling the arrestee to escape), and the officer believes on sufficient grounds (sōtō na riyū) that no other means will suffice to effectuate the arrest or forestall escape or interference; ${ }^{84}$ or (3) the officer is enforcing a warrant or order for arrest or detention on a person who resists or attempts to escape (or a third person intervenes for either purpose), and the officer has sufficient reason to believe no other means will suffice to effectuate the arrest or forestall escape or interference. ${ }^{85}$

73. Code of Crim. P. art. 212(2).

74. See S. DANDo, supra note 1, at 310-11. The concept, derived from Continental European systems, see id. at 311 , had been a part of the Code of Criminal Instruction of 1882, see J. DE BECKER, supra note 38, at 401; see also 1927 CODE OF CRIM. P.

75. Code of Crim. P. art. 210(1).

76. Predicate offenses must be punishable by imprisonment with or without forced labor for life or a term of three years or more. Id.

77. Id. The usual criteria for issuance of a warrant under Article 210(2) of the Code of Criminal Procedure govern Article 210(2).

78. See S. Dando, supra note 1, at 316-17 (citing and discussing precedent).

79. The United States Supreme Court has developed a doctrine that limits the use of deadly force in arrests on the premise that injury or death is a form of seizure of the person that must meet the constitutional reasonableness requirements of the fourth amendment. See Graham v. Connor, 490 U.S. 386 (1989); Tennessee v. Garner, 471 U.S. 1 (1985).

80. Police Duties Law, Law No. 163, 1954.

81. Id. art. 7 (main clause). See generally S. Dando, supra note 1 , at 309.

82. Police Duties Law art. 7 (main clause) (referring to Penal Code art. 36). See S. Dando, supra note $61, \S 6.06$.

83. Police Duties Law art. 7 (main clause) (referring to Penal Code art. 37). See S. Dando, supra note $61, \S 6.07$.

84. Police Duties Law art. 7(i).

85. Id. art. 7 (ii). 
Whatever the statutory basis for an arrest, the Constitution expressly requires that an arrested person be informed immediately of the charges on which arrest and detention are based. ${ }^{86}$

\section{Searches and Seizures.}

a. Search limitations. Article $35(1)$ of the Constitution of Japan is substantially equivalent to the warrants clause of the fourth amendment to the United States Constitution in providing that " $[t]$ he right of all persons to be secure in their homes, papers and effects against entries, searches and seizures shall not be impaired, except upon warrant issued for adequate cause and particularly describing the place to be searched and things to be seized." 87 Although there is no precise equivalent to the "reasonableness" clause of the American fourth amendment, 88 a somewhat similar aim is accomplished through a cross-reference in Article 35(1) to the provisions of Article 33 requiring arrest warrants other than in instances of flagrant delict. ${ }^{89}$

The Code is the source of the detailed provisions of Japanese law governing searches and seizures. In contrast to United States law, which tends in practice to restrict the use of search warrants to the investigative phase of criminal proceedings, ${ }^{90}$ Japanese criminal procedure envisions the use of judicially approved orders for search and seizure throughout the pendency of criminal proceedings. However, one should note an important procedural distinction, significant in a number of contexts, ${ }^{91}$ between suspects (higisha) and accused persons (hikokunin). Under U.S. law, the term "suspect" functions primarily in an informal or functional sense,, 92 and the

86. 1947 Const. art. 34. See also CoDE of CrIm. P. art. 203(1), which, in addition to requiring information about the "essential facts of the crime," mandates mention of the fact that the arrested person is entitled to select a defense attorney and to submit any explanation he or she wishes. See $\mathrm{S}$. DANDo, supra note 1 , at 314,315 . However, these procedures are accomplished not by the public prosecutor's assistant officer or by the judicial police officer who made the arrest, but by the judicial police officer to whose custody the arrested person has been transferred under Article 202 of the Code of Criminal Procedure. This does not appear to be viewed as infringing the "at once" (tadachi ni) mandate of Article 34 of the Constitution.

87. Compare U.S. ConsT. amend. IV (" $[\mathrm{N}]$ o warrants shall issue, but upon probable cause, supported by oath or affirmation, and particularly describing the place to be searched, and the persons or things to be seized.").

88. The American clause provides: "The right of the people to be secure in their persons, houses, papers, and effects, against unreasonable searches and seizures shall not be violated." Id.

89. See supra notes 70-78 and accompanying text. See also Japan v. Arima, 15 Keishū 915 (Sup. Ct., G.B., June 7, 1961) (search incidental to and at time and place of arrest).

90. There is, of course, no temporal limitation built into, at least directly, the American law of searches and seizures, although there is some incongruity in the jurisdictional allocation in Federal Rule of Criminal Procedure 4l (a) of the competence of courts of record to issue search warrants to federal magistrates or state judges if trial jurisdiction has vested in a district court based on the filing of an indictment or information. For the most part, procedures for discovery, FED. R. CRIM. P. 16, and issuance of subpoenas duces tecum, id. and FED. R. CRIM. P. 17(c), including grand jury subpoenas, are the usual methods of achieving functions equivalent to search warrants following the formal commencement of adversary criminal proceedings.

91. See, e.g., infra notes 133-179 and accompanying text (detention), notes 222-245 and accompanying text (counsel).

92. In Escobedo v. Illinois, 378 U.S. 478 (1964), the United States Supreme Court used the terminology of "focus on a particular suspect" as critical to the attachment of sixth amendment- 
formal procedural status of "defendant" or "accused" arises only with the formal initiation of adversarial criminal proceedings through a complaint or other provisional pleading. ${ }^{93}$ Japanese doctrine, in contrast, is patterned on the classical European legal construct and draws a significant line between suspects and accused persons, at times with reference to the existence or nonexistence of rights, ${ }^{94}$ and even more frequently concerning competence to accomplish procedural acts.

This latter distinction is demonstrated in the area of judicial authorization of searches, seizures, and inspection ${ }^{95}$ as provided in the Code. Before the initiation of criminal trial proceedings through the filing of an accusatory instrument, ${ }^{96}$ applications for warrants of search, seizure, and inspection are submitted to a judge and not a court. ${ }^{97}$ After an accusatory instrument has been submitted, however, the responsibility for issuance of an order of search, seizure, or inspection lies with the court itself (saibansho), not with an individual judge (saibankan). ${ }^{98}$

based controls on custodial interrogation. However, that constitutional rationale was swiftly replaced in Miranda v. Arizona, 384 U.S. 436 (1966), with a doctrine derived from the fifth amendment privilege against self-incrimination. Escobedo has not survived as an independent criterion for determining the constitutionality of interrogation in instances in which the sixth amendment right to counsel has not yet attached. See Michigan v. Tucker, 417 U.S. 433, 438 (1974); Frazier v. Cupp, 394 U.S. 731, 739 (1969).

93. This has been dealt with primarily concerning the applicability to interrogation of the sixth amendment right to counsel, see, e.g., Moran v. Burbine, 475 U.S. 412 (1986); Maine v. Moulton, 474 U.S. 159 (1985); Brewer v. Williams, 430 U.S. 387 (1977), and lineup procedures, see, e.g., Gilbert v. California, 388 U.S. 263 (1967); United States v. Wade, 388 U.S. 218 (1967); of. Manson v. Brathwaite, 432 U.S. 98 (1977) (due process fairness is the exclusive prerequisite for identification procedures conducted before the initiation of adversary criminal proceedings).

94. That is strikingly true in comparing the rights accorded to "accused persons" in Article 37 of the 1947 Constitution, particularly regarding the right to counsel, see infra notes $222-45$ and accompanying text, with those set forth for the populace generally in Articles 33 through 35 of the 1947 Constitution.

95. Inspection (kenshō) is a procedure for the discovery of facts, CODE OF CRIM. P. art. 128, and includes personal (physical or mental) examinations, autopsies, exhumations, destruction of property (for purposes of access to other material or as necessary to the performance of other acts of inspection and other necessary acts). See S. Dando, supra note 1, at 275-77, 319-20; H. TAmiYa, Chūshaku Keijisoshōhō (Commentaries on Code of Criminal Procedure) 149 (1980).

On precedent relating to urinalysis pursuant to court order, see Cleary, supra note 70 , at 146-47 (discussing Japan v. Goto, 34 Keishū 300 (Sup. Ct., G.B., Oct. 23, 1980)) (finding the process lawful because it had been implemented by a doctor in a hospital); $c$. Schmerber v. California, 384 U.S. 757 (1966) (no fourth amendment violation in blood-testing under aseptic circumstances).

96. See Code of Crim. P. arts. 247, 256; S. Dando, supra note 1, at 346-47.

97. Code of Crim. P. art. 218(1) (on application of a public prosecutor, public prosecutor's assistant officer, or judicial police official, when necessary for the investigation of an offense).

98. These powers inhere in the individual official and are not derived from his or her formal procedural affiliation with a court. See S. Dando, supra note 1 , at 57 . One also should note a second usage generally translated as "judge," namely, an official category of governmental official (hanji), which is significant in terms of appointment and status. See Court [Organization] Law (Saibanho), Law No. 59, 1947, arts. 39-40 (appointment and dismissal of Supreme Court Justices and judges of inferior courts), art. 43 (qualification for appointment as assistant judge (hanjiho)); S. DANDo, supra note 1, at 49. Accordingly, a hanji or hanjiho, depending on the circumstances, may perform procedurally significant acts as a saibankan independent of a court or may function as a saibansho if constituting a single-judge court under Court Law art. 26(1) (district court), art. 31 -4 (family court), or art. 35 (summary court). 
In applying for a warrant or order authorizing the examination of a person, an official ${ }^{99}$ must establish the necessity for the examination, as well as the gender and the physical condition of the person to be examined. ${ }^{100}$ The particularity requirements of the Constitution ${ }^{101}$ are supplemented by Code requirements governing the contents of a warrant or order. ${ }^{102}$ In addition, the issuing court or judge must authorize expressly any nighttime searches, seizures, or examinations. ${ }^{103}$ Certain privileges must be respected when issuing search and seizure authorizations, ${ }^{104}$ and caution must be maintained to safeguard confidentiality and avoid harm to the reputation of anyone subjected to a search or seizure. ${ }^{105}$

Designated classes of officials are authorized to conduct limited searches and seizures without advance judicial authorization. Police officers are empowered to conduct a search of an arrestee's person for dangerous weapons following any form of arrest under the Code. ${ }^{106}$ Public prosecutors and their assistant officers, or judicial police officials who carry out an arrest under warrant or based on a flagrant delict arrest also may "search, seize or inspect" at the situs of the arrest. ${ }^{107}$ Articles dropped or left behind by anyone (including a suspect or accused person) may be seized, and no formal

99. An applicant must be a public prosecutor, a public prosecutor's assistant officer, see Public Prosecutor's Office Law (Kensatsucho hō), Law No. 61, 1947, art. 27, or a judicial police official, CODE of Crim. P. art. 218(1). The term "judicial police official" (Shihō kensatsu shokuin) is a term of criminal procedural significance, id. arts. 189(1), 190, separate from the governmental employment status of persons appointed as police officers under the Police Law (Keisatsu hō), Law No. 162, 1954. See generally S. Dando, supra note 1, at 97-99; R. Rinalducci, Japanese Police ESTABLISHMENT 121, 206, 221-23 (1973).

100. Code of Crim. P. art. 218(4).

101. 1947 Const. art. 35(1).

102. Code of Crim. P. arts. 107, 219; Rule of Crim. P. (Keijisoshō kisoku), Supreme Court R. No. 32,1948 art. 155.

103. Code of CRIM. P. art. 116; but see id. arts. 116(2) (allowing execution commenced before sunset to continue after), 117 (excepting searches of places deemed to be used habitually for gambling, lotteries, or other acts prejudicial to good morals, or inns, restaurants, or other places to which the public has access during the nighttime, but only during the hours such establishments are open to the public), 222(4)-(6) (equivalent limitations on warrants or orders of inspection).

104. For example, certain persons against whom orders of seizure have been issued under Article 99(2) of the Code ("a court may designate articles to be seized and order the owner, possessor or custodian thereof to produce them") may legally refuse to turn over the designated matter. See id. arts. 104 (consent of Diet House or Cabinet required before compliance, if the person against whom process has been directed is a member of either); 105 (specific professional and religious functionaries may refuse to comply with seizure orders, provided the protected individual has not consented to release of materials sought, and the refusal to accede to the process is not intended to shield an accused who is not a protected client at the time).

105. Rule of Crim. P. art. 93. If a search warrant is to be executed against the person of a female in other than exigent circumstances, another adult woman must be present. CODE OF CRIM. P. art. 115.

106. Police Duties Law art. 2(4).

107. Code of CRIM. P. art. 220(1)(ii). Without an authorizing warrant, the authorities can also enter a residence or premises, buildings, or vessels under the control of persons for the purpose of searching for a suspect. Id. arts. 220(1)(i), 220(3). See generally Cleary, supra note 70, at 144-46 (discussing lower court precedents relating to search activities incidental to arrest). For discussion of precedent sustaining the constitutionality of police photography of demonstrators and occupants of speeding vehicles under Article 13 of the 1947 Constitution, which guarantees the dignity of the individual and the right to life, liberty and pursuit of happiness, see id. at 135-36. 
procedures are required concerning anything voluntarily produced or surrendered by its owner, possessor, or custodian. ${ }^{108}$

b. Secrecy of communications. The Constitution, perpetuating but considerably strengthening a concern in the Meiji Constitution, ${ }^{109}$ states that the secrecy of any means of communication is not to be violated. ${ }^{10}$ Although the constitutional language appears unqualified, the Code provides for court orders to seize or produce mail, telegrams, or other communications if a suspect or accused was either the transmitter or recipient. ${ }^{11}$ Other communications must relate to the case in question before a court or judge may authorize their seizure. ${ }^{112}$ Although the constitutional right of privacy embodied in Article 21 is implicated in these Code provisions, the provisions, nonetheless, generally seem to be considered constitutional. ${ }^{113}$

c. Exclusion of evidence. The sole reference the Constitution makes to the exclusion of evidence is a provision requiring the exclusion of confessions that do not meet mandated standards. ${ }^{114}$ This rule would have no applicability, for example, to evidence seized in violation of Article 35. However, the Supreme Court of Japan apparently has recognized that an exclusionary rule can be applied to the fruits of an unlawful search if such exclusion would be necessary to deter unlawful police activity. ${ }^{115}$ The Code of Criminal Procedure requires that evidence obtained incidentally to an emergency arrest must be returned immediately if an arrest warrant is not obtained afterwards. ${ }^{16}$ That rule is not, however, an exclusionary rule as such. ${ }^{117}$

d. Interrogation. The Constitution provides that confessions made under compulsion, torture, or threat, or after prolonged arrest or detention, are

108. Code of Crim. P. arts. 101, 221.

109. MeIJ Const. art. 26 (except in instances set forth in law, the secrecy of letters of Japanese subjects must remain inviolable). See $\mathrm{H}$. ITo, supra note 32 , at 54 (opening or destruction of letters "will not be tolerated, except in matters of criminal investigation or in times of war or of emergency, or in cases specified by express provisions" of law); N. MATsunami, supra note 16, at 253 (identical language to Prince Ito's).

110. 1947 Const. art. 21(2), final clause. On potential constitutional issues concerning wiretapping, see Cleary, supra note 70 , at $136-38$.

111. Code Of Crim. P. arts. 100(1), 222.

112. Id. arts. $100(2), 222$. Notice must be given to the sender or addressee unless there is fear that notification may obstruct the underlying criminal procedures. Id. art. 100(3).

113. See, e.g., S. Dando, supra note 1, at 270; H. TAMIYA, supra note 95, at 124.

114. 1947 Const. art. 38(2); Code OF CRIM. P. art. 319(1). See infra note 118 and accompanying text.

115. Japan v. Hashimoto, 32 Keishū 1672, 1682-83 (Sup. Ct., 1st P.B., Sept. 7, 1978), discussed in Dando, supra note 43, at 645 . The Court's rationale was similar to that of the United States Supreme Court in, e.g., Stone v. Powell, 428 U.S. 465 (1976); United States v. Peltier, 422 U.S. 531 (1975); Michigan v. Tucker, 417 U.S. 433 (1974).

116. Code of Crim. P. arts. 210, 220(2). See supra notes 75-78 and accompanying text.

117. Compare a motion for return of property under Federal Rules of Criminal Procedure 41(e) with a motion to suppress evidence under Federal Rules of Criminal Procedure 12, $41(\mathrm{f})$. See also H. TAMIYA, supra note 95 , at 246. 
inadmissible as evidence. ${ }^{118}$ That rule, of course, fixes an important level of protection for both suspects and accused persons, because the ban covers confessions without regard to the procedural status of their makers at the time they were made. However, certain statutory provisions must be considered in determining the status of interrogation under Japanese law.

Under the Police Duties Law, police officers are empowered to stop and question persons under specified circumstances: (1) when the officers have a rational basis to determine that individuals have committed or are on the point of committing crimes; ${ }^{119}$ and (2) when, on the same basis, individuals are thought to have information about crimes that have been or are about to be committed. ${ }^{120}$ If the officer considers the location of the encounter disadvantageous to the information source or an obstruction to traffic, the individual may be requested to accompany the officer to a nearby police station, police box, or residential police box for questioning. ${ }^{121}$ However, a requested individual is under no duty to accompany the officer elsewhere or to answer any questions at either the original location or a police facility to which the officer and individual have repaired. ${ }^{122}$ If an individual refuses to cooperate, a police officer may take only one of the measures allowed against informants who are not suspects or accused persons in the case to which their information relates. ${ }^{123}$

118. 1947 Const. art. 38(2), restated in part in Code of CRIM. P. art. 319(1). Representative precedents on voluntariness include Japan v. Okayama, 24 Keishū 1670 (Sup. Ct., G.B., Nov. 25 , 1970) (effect of psychological pressures on voluntariness); Japan v. Abe, 20 Keishū 537 (Sup. Ct., 2d P.B., July 1, 1966) (confession involuntary in light of public prosecutor's representations concerning possibility of suspension of institution of prosecution); Japan v. Okamura, 18 Keishū 177 (Sup. Ct., 2d P.B., June 1, 1964) (polygraph alone did not make confession involuntary, but involuntariness existed on the basis of the entirety of circumstances). See also Armstrong, supra note 14, at 194-97. Derivative evidence arguably is included in the ban. See H. TAmiya, supra note 95, at 362-63.

119. Police Duties Law art. 2(1) ("goriteki ni handan shite . . . utagau ni tariru sōtō na riyū no aru"). On searches incidental to the exercise of this power, see Cleary, supra note 70, at 133-34.

120. Police Duties Law art. 2(1).

121. Id. art. 2(2).

122. Id. art. 2(3). See generally Cleary, supra note 70, at 130-31 (discussing precedents on stopping and questioning under the Police Duties Law), 131-33 (discussing traffic stop precedents).

123. See S. DANDo, supra note 1, at 307-08. Persons other than suspects can be asked to appear at the office of a public prosecutor, public prosecutor's assistant officer, or judicial police official for questioning concerning a case under investigation. CODE of CRIM. P. art. 223(1). The individual is under no duty to comply with the request to appear or to remain after questioning, id. arts. 223(1), 198(1), but if the individual makes a statement it may be reduced to protocol form and read to the source, id. arts. 223(2), 198(3)-(4). The source may sign and seal the protocol if he or she affirms it is true, but is under no duty to do so. Id. arts. $223(2), 219(5)$. If the individual refuses to appear or disclose the information in his or her possession, the public prosecutor can request a judge to question the individual before the first day of public trial, at which the accusatory instrument takes formal effect. Id. art. 226. If the individual has given a statement to an investigating official under Code of Criminal Procedure Article 223(1) and the official believes the individual may be subjected to pressure to alter or withdraw the statements if testifying at public trial, and the testimony will be essential to proving the guilt of the accused, the official can ask that the individual be questioned by a judge as a witness before the first day of public trial. Id. art. 227(1). The applicant official must make a prima facie showing of the grounds of necessity. Id. art. 227(2). A judge granting the request possesses the same powers as a court or presiding judge that examines a witness, $i d$. art. 228(1), and the judge may allow the accused person or suspect, or defense counsel, to be present, id. art. 228(2). 
A public prosecutor, public prosecutor's assistant officer, or judicial police official can request a suspect to appear for questioning if it is considered necessary to an investigation. ${ }^{124}$ If the suspect appears, the investigating official must inform the individual that he or she is not required to make a statement against his or her will. ${ }^{125}$ If the suspect makes a statement, it is reduced to protocol form and read to the suspect for verification; changes are entered as additional material in the protocol. ${ }^{126}$ Any protocol so obtained is admissible into evidence at trial as a document containing a statement made by the accused person. ${ }^{127}$

\section{B. Detention and Release}

The Constitution contains no express provision supporting a claim to bail or other form of preconviction release. Instead, Article 34 prohibits detention without adequate cause, and requires that, upon the demand of someone in detention, the grounds for detention be established in open court in the presence of the detainee and the detainee's counsel.128 Because these requirements are, in a sense, peripheral rather than central, determinations of custody versus liberty are made in accordance with the detailed provisions of the Code of Criminal Procedure. Once again, the formal legal distinctions between suspects and accused persons ${ }^{129}$ are essential to a determination of claims to release.

The Anglo-American and Japanese criminal justice systems approach from theoretical bases that are polar opposites the question of which suspects or accused should be held in custody and which should be released. The AngloAmerican system assumes that almost all criminal proceedings will commence with the arrest of offenders; only in a small fraction of criminal cases will the first significant procedural act be the issuance of a grand jury indictment, followed by the issuance and execution of a bench warrant for the arrest of an indicted person. ${ }^{130}$ Hence, although some commentators advocate the

124. Code of Crim. P. art. 198(1). The individual is under no duty to appear or remain, however, unless he or she is under arrest or in detention at the time. Id. See generally Cleary, supra note 70 , at 124-26.

125. Code of Crim. P. art. 198(2). The warning does not extend, however, to the right to withdraw under Code of Criminal Procedure Article 198(1).

126. Id. art. 198(4). If the suspect affirms the correctness of the contents of the protocol, he or she is asked to sign or seal it, but the suspect may refuse to do so. Id. art. 198(5).

127. Id. art. 322(2) (The document is admissible, provided the statement appears to have been made voluntarily.). Even should that provision not apply, a protocol or statement could be admitted with the concurrence of the court, the public prosecutor, and the accused person, id. art. 326, or used for impeachment purposes under Code of Criminal Procedure Article 328. See generally S. Dando, supra note 1 , at 306-07.

128. Article 34 of the 1947 Constitution also requires that persons under arrest or detention be informed immediately of the charges lodged against them. The provision was not implicated when a foreigner was required to remain in an airport hotel while authorities inquired into his eligibility to remain in Japan. Japan v. Bye (phonetic based on katakana), 617 Hanrei Jihö 25 (Sup. Ct., 1st P.B., June 25, 1971).

129. See supra notes $91-98$ and accompanying text.

130. FED. R. CRim. P. 9. If a state has replaced grand jury indiciment procedures with a preliminary examination-information system, the initiation of criminal proceedings through $a b$ initio indictment is exceptionally rare. 
greater use of summons in lieu of arrest, ${ }^{131}$ the primary focus of contemporary Anglo-American criminal procedure has been on the release of offenders following arrest and production, and the constitutionality of the socalled preventive detention designed to protect victims, witnesses, evidentiary data, and the community against injurious activities. ${ }^{132}$ In contrast, the theoretical premises on which the Japanese system rests are that persons will remain free, whether before or after an accusatory instrument has been filed, unless affirmative action is taken by public prosecutors, their assistant officers, or judicial police officials to request a judge or a court (depending on the stage of a criminal prosecution) to terminate that state of freedom. Either the Anglo-American or the Japanese system could be administered to achieve about the same ratio of nonrestrained and detained persons-in the United States by increased use of preventive detention, as well as by the traditional manipulation of bond amounts imposed on defendants where that remains possible, and in Japan by increasing the frequency with which detention orders are sought against suspects and accused persons.

\section{Detention Before Initiation of Public Trial Proceedings. As discussed earlier, ${ }^{133}$} arrests ordinarily must be accomplished pursuant to a warrant issued by a judge or court; only flagrant delict and emergency arrests constitute exceptions. After a judicial police officer has either arrested a suspect or received custody from another arresting officer, ${ }^{134}$ the officer must immediately release the individual if further custody is unnecessary, or transfer the custody of the suspect to a public prosecutor within forty-eight hours. ${ }^{135}$ Failure to transfer the suspect within that time necessitates his or her immediate release. ${ }^{136}$ A similar forty-eight-hour limit governs public prosecutors who have made arrests or received custody of arrested suspects from public prosecutors' assistant officers; they must seek a detention warrant from a judge, file an accusatory instrument within forty-eight hours, or release the suspect at the expiration of that period. ${ }^{137}$

131. See Standards for Criminal Justice $\$ \S 10-2.1$ to 2.3 (citations by police in lieu of arrest), 10-3.1 to 3.4 (summons in lieu of arrest warrant), and commentary (2d ed. 1980).

132. See, e.g., Bail Reform Act of 1984, 18 U.S.C. $\$ \$ 3141-3142$ (West Supp. 1989), discussed in, e.g., 1 B. George, Comprehensive Crime Control. Act of 1984, ch. 2 (1984 \& 1990 Supp.). The United States Supreme Court affirmed the basic constitutionality of the preventive detention aspects of the law in United States v. Salerno, 481 U.S. 739 (1987).

133. See supra notes $70-78$ and accompanying text.

134. Public prosecutor's assistant officers who have arrested persons pursuant to warrants must immediately transfer custody of the arrestees to a public prosecutor, and judicial police constables must transfer custody of arrestees to a judicial police officer. CoDE of Crim. P. art. 202. Similar procedures are mandated when a flagrant delict arrest has been consummated. Id. arts. 214-215.

135. Id. art. 203(1). The suspect must be informed immediately of the essential facts of the crime or crimes concerning which charges have been made, as well as the right to select defense counsel, id., unless the suspect already has retained counsel, id. art. 203(2). In the latter event, no notification concerning that right is needed. Id. Precedents on the length of questioning before arrest are discussed in Cleary, supra note 70 , at 126-28.

136. Code of Crim. P. art. 203(3). See generally S. Dando, supra note 1, at 314-15.

137. Code of Crim. P. art. 204. See generally S. DANDo, supra note 1, at 315-16. Immediate release is required before the expiration of the 48 -hour period if the public prosecutor perceives no need to keep the suspect in custody. Code of Crim. P. art. 204(1). 
If a public prosecutor has received custody of an arrested suspect and if the case documents have been transferred to him or her from a judicial police officer, the public prosecutor must release the suspect immediately if there is no perceived need to continue the suspect in custody, or within twenty-four hours either obtain a judicial detention order ${ }^{138}$ or institute prosecution. ${ }^{139}$ If the time limit is not met, the suspect must be discharged from custody immediately. ${ }^{140}$ Accordingly, when custody initiated by a judicial police officer is followed by a transfer of an arrested suspect and case documents to a public prosecutor, seventy-two hours is the maximum length of custody permitted without authorization by a judge. ${ }^{141}$

If for unavoidable reasons a prosecution cannot be commenced within the forty-eight, twenty-four, or seventy-two-hour time limits, a public prosecutor can request a judge to detain the suspect, based on a prima facie showing of the reasons for noncompliance with the time limits. ${ }^{142}$ The recipient judge must find that the asserted grounds existed before a detention order can issue. ${ }^{143}$

When a judge has received a request to detain a suspect, the judge ${ }^{144}$ must issue an order of detention unless he or she determines there is no ground for detention or no justification for a failure to meet the Code's time limits on detention. ${ }^{145}$ Arguably, a judge should refuse a prosecutorial request for detention if detention does not appear necessary, even though legal grounds exist to support detention. ${ }^{146}$ If a detention order issues, it is valid for ten days, ${ }^{147}$ within which public prosecution must be initiated or an extension order must be obtained. ${ }^{148}$ Based on a finding of unavoidable circumstances, the judge may extend the detention order for an additional time not to exceed ten days. ${ }^{149}$ Accordingly, in almost all cases, the maximum period of precharging detention is twenty-three days, ${ }^{150}$ but in certain sensitive

138. Code of Crim. P. art. 205(1). See generally S. Dando, supra note 1, at 315.

139. Code of Crim. P. art. 205(3).

140. Id. art. $205(4)$.

141. Id. art. $205(2)$.

142. Id. art. $206(1)$.

143. Id. art. 206(2).

144. The judge has the same powers as a court addressing the detention of an accused person under Article 60 of the Code of Criminal Procedure (based on Article 207(1)), except that the judge cannot fix bail. Id. art. 207(1). The reason for the limitation is found in the brief duration of detention before public prosecution begins. See infra notes 147-52 and accompanying text. See also S. DANDo, supra note 1 , at 318 .

145. Code of Crim. P. art. 207(2).

146. See S. DANDo, supra note 1 , at 317-18.

147. Code of Crim. P. art. 208(1).

148. Id. art. 208(2).

149. Id.

150. The maximum is three days if a judicial police officer has transferred custody and documents to a public prosecutor, followed by a ten-day initial period of detention, followed in turn by an extension order not to exceed ten days in length.

Detention during this phase can be in a detention center (kōchisho) or a police custody cell (ryūchisho), but even after the institution of public prosecution, police custody cells may be designated as substitute houses of detention (daiyo kangoku) under Article 1(3) of the Prison Law, Law No. 28, 1908. An important practical consequence of the latter is that suspects and accused persons can be held in facilities administered by police authorities and not a prison or detention 
cases $^{151}$ an additional period of detention not to exceed five days can be authorized based on a showing of unavoidable circumstances. ${ }^{152}$

2. Detention Following Institution of Prosecution. If public prosecution is instituted against persons not in detention, the normal practice is to send a summons to them requiring them to appear before the court. ${ }^{153}$ If there is noncompliance with a summons or apprehension that an accused person may not comply without good reason, ${ }^{154}$ or if the accused person has no fixed dwelling, ${ }^{155}$ the court before which prosecution has been initiated is authorized to produce (köin-suru) an accused person. ${ }^{156}$ After the warrant of production issued by the court has been executed and the accused person has been brought before the court, ${ }^{157}$ custody may continue for only twenty-four hours unless a warrant of detention has issued during that period. ${ }^{158}$

Detention is allowed on the basis of sufficient reasonable grounds to suspect that an accused person has committed an offense and that at least one of three specified grounds is present: (1) the accused person has no fixed dwelling; (2) there is sufficient reasonable ground to suspect the accused person may destroy evidence; or (3) the accused person has escaped or there is sufficient reasonable basis to suspect that he or she may do so. ${ }^{159}$ The basic maximum period of detention is two months from the date of the institution of prosecution. ${ }^{160}$ However, in any criminal prosecution, one extension of one month's duration can be ordered at the expiration of the initial two-

center administered by the Ministry of Justice. This has been alleged as a reason for significant abuse of the rights of detainees. See Nakayama, National Report of Japan, 49 R. INT. D.P. 217, 225-32 (1978); Saito, "Substitute Prison": A Hotbed of False Criminal Charges in Japan, 2 Konan U. J. Soc. ScI. 51, 59-61 (1988).

151. Code of Crim. P. art. 208(2) (crimes concerning insurrection); Penal Code arts. 77-80 (insurrection), $81-88$ (foreign aggression), 92-94 (foreign relations), 106-07 (riot).

152. Code of CRIM. P. art. 208(2).

153. Id. art. 57. Summons practice is delineated in Articles 63 and 65 of the Code of Criminal Procedure. The fixed minimum period between notice and appearance is 12 hours, RuLES OF CRIM. P. art. 67(1), but an accused person can chose to appear before the 12 hours have passed, id. art. 67(2). Presence most usually is for the purpose of participation in public trial proceedings, but also can be used for other purposes like a physical examination of an accused person. Id. art. 102. See generally S. DANDo, supra note 1, at 254.

154. Code of Crim. P. art. 58(ii).

155. Id. art. 58(i).

156. Id. art. 58 (main clause).

157. For the procedures governing production, see id. arts. 64, 66-76. Upon production, an accused person must be given immediate notice of the alleged facts (in summary form), the right to counsel if counsel has not been selected, and the right to request appointment of counsel based on financial inability or other reason. Id. art. 76(1). See generally S. DANDo, supra note 1, at 254-56.

158. Code of Crim. P. art. 59. Before the first day of public trial proceedings, detention matters continue to be dealt with by a judge (not the court), who possesses the same authority as a court or presiding judge. Id. arts. $280(1)$, (3).

159. Id. art. 60(1). However, when relatively minor offenses are charged, the sole basis for detention is lack of a fixed residence. Id. art. 60(3). Unless an accused person has escaped, a court cannot order detention until after it has informed the accused person of the charges and has heard his or her statement concerning them. Id. art. 61. For the procedures relating to warrants of detention, see id. arts. 70-74, 77. See generally S. DANDo, supra note 1, at 258; Armstrong, supra note 14, at 190-94. On conditions of detention, see Code of Crim. P. arts. 78-81; S. Dando, supra note 1, at 257.

160. Code of Crim. P. art. 60(2). 
month period, based on a finding of concrete grounds necessitating continued detention. ${ }^{161}$ Moreover, one-month extension orders can be obtained, without a limitation on the maximum number of extensions, if any of the following grounds exists: (1) the charged offense is punishable with death or imprisonment with or without forced labor for life or a minimum term exceeding one year; ${ }^{162}$ (2) the accused person habitually has committed offenses punishable by imprisonment with or without forced labor for a maximum term of three years or more; ${ }^{163}$ (3) there is sufficient reasonable basis to suspect that the accused person may destroy evidence; ${ }^{164}$ or (4) the name or residence of the accused person is unknown. ${ }^{165}$

\section{Release from Detention.}

a. Lack of grounds for continued detention. The Constitution requires that, at the demand of the person in detention, the cause for detention be indicated in open court in the presence of the accused person and his or her counsel. ${ }^{166}$ That requirement is set forth in detail in the Code of Criminal Procedure, which provides that either an accused person in detention ${ }^{167}$ or certain designated persons acting on her or his behalf ${ }^{168}$ may request an indication of the grounds for detention. ${ }^{169}$ As required by the Constitution, the indication of grounds must be accomplished in open court ${ }^{170}$ with judges ${ }^{171}$ and court clerks in attendance. ${ }^{172}$ The constitutional mandate that the proceedings be accomplished in the presence of the accused person and defense counsel is repeated, with certain specified exceptions. ${ }^{173}$ After the proceedings have been opened, the court must afford opportunities to a public prosecutor, the accused person, defense counsel, and any person who may have submitted a

\footnotetext{
161. Id.

162. Id. (referring to id. art. 89(i)).

163. Id. (referring to id. art. 89(iii)).

164. Id. (referring to id. art. 89(iv)).

165. Id. (referring to id. art. 89(vi)).

166. 1947 Const. art. 34. See supra note 128 and accompanying text.

167. Code of Crim. P. art. 82(1).

168. Requests may be submitted by a defense counsel, legal representative, curator, spouse, lineal relative, sibling, or other interested person. Id. art. 82(2).

169. If, before action can be taken on the request, the detainee is released on any basis (release on bail, suspension of the enforcement of a warrant of detention, or rescission or loss of effect of the warrant), the request becomes inoperative. Id. art. 82(3). If two or more requests are submitted concerning the same detention, action is taken on the first one submitted and the rest are dismissed by a ruling after reasons for detention have been indicated. Id. art. 86 .
}

170. Id. art. $83(1)$.

171. If the predicate charges are determined by a collegiate court, all members participate in the process, id. art. 85, although the presiding judge communicates the grounds for detention, id. art. $84(1)$.

172. Id. art. $83(2)$.

173. Id. art. 83(3). Indication procedures may continue if an accused person is unable to appear because of unavoidable circumstances (such as illness) and consents to the proceedings in his or her absence, or if the accused person does not object to proceedings in the absence of defense counsel who fails to appear. Id. This rather clearly rests on a theory of waiver of the constitutional requirements. 
request on behalf of the accused person to state their views on the matter. ${ }^{174}$ If the reasons underlying the original warrant of detention no longer pertain, the court must rescind the warrant of detention immediately ${ }^{175}$ if the accused person has not already been released on some other basis. ${ }^{176}$

A public prosecutor, an accused person in detention, or persons acting on his or her behalf also may request rescission of a warrant of detention based on termination of the grounds or necessity for detention. ${ }^{177}$ This request differs in form from the special procedure requesting an indication of reasons for detention. ${ }^{178} \mathrm{~A}$ court is also required to rescind a warrant of detention (or grant release on bail) on the application of anyone authorized to request bail or on the court's own motion, if a warrant of detention has been in force for an unreasonable period. ${ }^{179}$

b. Bail. Either an accused person in detention, or his or her defense counsel, legal representative, curator, spouse, lineal relative, or sibling may request release on bail, ${ }^{180}$ unless the accused person has been released in the interim. ${ }^{181}$ The Code purports to create a plenary right to release on bail, ${ }^{182}$ but allows bail to be denied on any of the following grounds: (1) the charged offense is punishable with death or imprisonment with or without forced labor for life or a minimum term exceeding one year; (2) the accused person has a previous conviction of a serious offense; (3) the accused person habitually has committed offenses punishable by imprisonment with or without forced labor for a maximum term of three years or more; (4) there is a sufficient reasonable basis to suspect that the accused person may destroy evidence; (5) there is a sufficient reasonable basis to suspect that the accused person may inflict personal injury or property damage on or commit a threatening act toward the victim or someone else deemed to have information needed for the trial of the case, or a relative of either; or (6) the name or residence of the accused person is unknown. ${ }^{183}$ Bail must be granted if a warrant of detention has

174. Id. art. $84(2)$. The presiding judge, however, may order the submission of written, rather than oral, statements if that is deemed appropriate. Id. See generally S. Dando, supra note 1, at 26061 .

175. This is not explicit in the context of the procedure in question, but is provided for in Article 87(1) of the ensuing Code of Criminal Procedure. See S. Dando, supra note 1, at 261.

176. See Code of Crim. P. art. 87(2); cf. supra note 169 (release renders request inoperative).

177. Code of Crim. P. art. 87(1).

178. A person who is physically restrained not in accord with proper legal procedure may apply to a court for relief. Habeas Corpus Law, Law No. 199, 1948, art. 2(1). Any other person can do the same on behalf of the confined individual. Id. art. 2(2). Normally, however, this is to be done through an attorney as representative. Id. art. 3. There is no "exhaustion of remedies" requirement in the Habeas Corpus Law, $c f .28$ U.S.C.A. $\$ 2254$ (d) (West Supp. 1989), so that procedures under it constitute a full-fledged alternative to the indication of grounds procedures in the Code of Criminal Procedure, described in the main text above. See generally S. DANDo, supra note 1, at 261; 3 KodANSHA ENCYCLOPEDIA OF JAPAN 73 (1983).

179. Code of Crim. P. art. $91(1)$.

180. Code of Crim. P. art. 88(1). See generally S. Dando, supra note 1, at 265-67.

181. Code of Crim. P. art. 88(2).

182. Id. art. 89, main proviso. A court also may grant bail on its own motion if it deems that appropriate. Id. art. 90 .

183. Id. art. 89. 
been in effect for an unreasonably lengthy period. ${ }^{184} \mathrm{~A}$ court must hear the views of a public prosecutor before it determines to grant or reject a request for release on bail. ${ }^{185}$

With one exception, ${ }^{186}$ the only authorized form of release is on money bail; ${ }^{187}$ the Code does not provide for release on personal recognizance with or without condition. ${ }^{188}$ The court must set bail ${ }^{189}$ in an amount appropriate to assure the presence of the accused person, in light of the nature and circumstances of the offense, the strength of the evidence against the accused person, and the character and financial ability of the accused person. ${ }^{190}$ Once the decision has been entered to allow bail, the court can impose restrictions on the place of residence of the accused person and set any other conditions on release which the court considers proper. ${ }^{191}$ However, at least some nominal bail seemingly would have to be set as a prerequisite to the imposition of conditions on release.

Bail can be tendered by either an accused person or someone else, if the court allows; ${ }^{192}$ the court may also accept negotiable securities or a written undertaking submitted by someone other than the accused person, as approved by the court. ${ }^{193}$ A ruling granting release on bail does not become effective until the bail deposit has been accomplished. ${ }^{194}$

Bail, or the suspension of the enforcement of a detention order, can be rescinded upon the request of a public prosecutor or on the court's own motion, if any of the several grounds enumerated in the Code has been found to exist. ${ }^{195}$ The court can renew the bail ruling, but if it is rescinded, the court can order the forfeit of some or all of the money or other property in the

184. Id. art. $91(1)$.

185. Id. art. $92(1)$.

186. A court in its discretion may suspend the enforcement of a warrant of detention and entrust the accused person under detention to the charge of, for example, a relative or a protective institution, or restrict the residence of the accused person. Id. art. 95. See generally S. Dando, supra note 1 , at $267-68$.

187. Code of Crim. P. art. 93(1).

188. But see 18 U.S.C.A. \$ 3142(b), (g) (West Supp. 1989). See 1 B. George, supra note 132 , $\S \S 2.06-.07$. In some instances, matters that would be dealt with in the United States on the basis of release with or without conditions could be addressed through rescission or suspension of an order of detention. Consideration also should be given to the device of suspending prosecution under Code of Criminal Procedure Article 248. See Armstrong, supra note 14, at 197-200; Foote, Prosecutorial Discretion in Japan: A Response, 5 UCLA PAC. BAsin L.J. 96, $102-06$ (1986); George, supra note 36, at 269-70; Goodman, Exercise and Control of Prosecutorial Discretion in Japan, 5 UCLA PAC. BASIN L.J. 16, 36-43, 48-53 (1986).

189. Code of Crim. P. art. 93(1).

190. Id. art. 93(2). On the meaning of "strength of the evidence," see S. DaNDo, supra note 1, at 266.

191. Code of Crim. P. art. 93(3).

192. Id. art. $94(2)$.

193. Id. art. $94(3)$.

194. Id. art. $94(1)$.

195. Id. art. 96. The specified grounds are satisfied when the accused has: (1) failed to appear, without good reason, when summoned; (2) fled, or there is sufficient reason to believe that he or she is about to flee; (3) destroyed evidence of the crime, or there is sufficient reason to believe that he or she is about to do so; (4) inflicted or tried to inflict personal injury or property damage upon or performed intimidating acts toward the victim, some other person deemed to have information necessary to the trial of the case, or a relative of either; or (5) failed to abide by restrictions on 
custody of the court. ${ }^{196}$ The accused person also is returned to detention under procedures established in the Code. ${ }^{197}$ If there is no rescission or default, the deposited funds or securities are returned to the accused person. ${ }^{198}$

4. Contemporary Constitutional Issues. It is doubtful that the present system of preconviction detention and release contravenes the provisions of Article 34 of the Constitution; constitutional issues would come to the fore only if the Supreme Court of Japan were to embark upon an expansive interpretation of Article 31 , converting it clearly into a due process clause on the American pattern and extending it aggressively into the area of procedure just examined. Such a development appears exceedingly unlikely. Moreover, even if it did so, analogies to United States Supreme Court precedent would offer no support for an invalidation of the Japanese system; fourth amendment probable cause suffices to support detention on judicial order, ${ }^{199}$ and denial or revocation of release pending adjudication, based on determinations of danger of injury or death to victims or witnesses, of destruction of evidence, or of other serious danger to the community or the administration of criminal justice, violates neither the eighth amendment bail clause nor due process of law. ${ }^{200}$ If there is any deficiency in the Japanese system, it probably lies in the unavailability of any form of claim to release during periods of arrest or custody before the institution of criminal prosecution. $^{201}$ Nevertheless, as noted, that does not violate either Article 34 or Article 31 under the prevailing limited construction of those provisions.

Nevertheless, private sources in Japan, notably the Japan Civil Liberties Union ("JCLU"), 202 have attacked the present detention and release system, primarily in reliance on the fact that in 1979 Japan ratified the International Covenants on Economic, Social, and Cultural Rights and Civil and Political Rights. ${ }^{203}$ The principal contentions of the JCLU are that the Japanese law as applied $^{204}$ violates provisions of the Civil and Political Rights Covenant on the production and release of arrested and detained persons ${ }^{205}$ and the

residence or other conditions on release fixed by the court at the time bail was granted. Id. See generally S. DANDo, supra note 1, at 266-67.

196. Code of CRIM. P. art. 96(2). This can also be done on motion of a public prosecutor when the accused person has fled or failed to appear. Id. art. 96(3).

197. Id. art. 98. See generally S. DANDo, supra note 1, at 267.

198. Rules of Crim. P. art. 91. See S. Dando, supra note 1, at 292 n.111.

199. Gerstein v. Pugh, 420 U.S. 103, 116-19 (1975).

200. United States v. Salerno, 481 U.S. 739 (1987).

201. See supra notes $133-52$ and accompanying text.

202. Japan Civil Liberties Union, Citizens' Human Rights Report (1985) (portions of which are translated in 20 LAW IN JAPAN $30-73$ (1987)) [hereinafter JCLU REPORT].

203. G.A. Res. 2200A, 21 U.N. GAOR Supp. (No. 16) at 49, U.N. Doc. A/6316 (1966), reprinted in United Nations, Human Rights: A Compilation of International Instruments 8-15 (1983) (U.N. Publ. Sales No. E.83.ZIV.1) [hereinafter Civil and Political Rights Covenant]. See Repeta, The International Covenant on Civil and Political Rights and Human Rights Law in Japan, 20 LAW IN JAPAN 1, 2-3. 204. See JCLU REPORT, supra note 202, at 64-73.

205. Civil and Political Rights Covenant, supra note 203, art. 9(3). Anyone arrested or detained on a criminal charge shall be brought promptly before a judge or other officer authorized 
presumption of innocence. ${ }^{206}$ Whether the Civil and Political Rights Covenant is self-executing and paramount to the detention and release provisions of the Code of Criminal Procedure ${ }^{207}$ is a matter the Japanese courts ultimately will have to resolve. However, particularly as far as the "presumption of innocence" premise is concerned, if Japan is in violation of international standards, then so is the United States, for the United States Supreme Court has clearly held that the so-called presumption relates exclusively to the prosecution's burden of persuasion at the trial of criminal charges. 208

\section{Institution of Public Prosecution}

The Constitution is silent concerning the mechanism by which formal criminal charges are to be instituted.209 Under the Code of Criminal Procedure, ${ }^{210}$ prosecution is commenced through filing a written accusatory instrument with a competent court. ${ }^{211}$ Accused persons are promptly served with a copy of the instrument, ${ }^{212}$ summoned to appear, ${ }^{213}$ and expected in most instances to be present so that trial proceedings can commence. ${ }^{214}$ Upon

by law to exercise judicial power and shall be entitled to trial within a reasonable time or to release. It shall not be the general rule that persons awaiting trial shall be detained in custody, but release may be subject to guarantees to appear for trial, at any other stage of the judicial proceedings, and, should occasion arise, for the execution of the judgment. Id.

206. Id. art. 14(2). See also JCLU REPORT, supra note 202, at 73.

207. See Repeta, supra note 203, at 3-7.

208. See Bell v. Wolfish, 441 U.S. 520, 533 (1979); Taylor v. Kentucky, 436 U.S. 478, 483-86 (1978); In re Winship, 397 U.S. 358, 363-64 (1970). Cf. McCoy v. Wisconsin Court of Appeals, 486 U.S. 429, 436 (1988) (protection disappears after conviction; defendant-appellant assumes burden of convincing appellate tribunal that reversible error occurred at trial).

209. This contrasts with the fifth amendment of the U.S. Constitution, which requires grand jury indictments in federal capital or "otherwise infamous cases." The latter is taken to mean felonies (in federal practice, crimes punishable by imprisonment exceeding one year); misdemeanors may be prosecuted through information. FED. R. CRIM. P. 7(a). The fifth amendment grand jury requirement is not incorporated in fourteenth amendment due process, Hurtado v. California, 110 U.S. 516 (1884); therefore, states may eliminate the grand jury system or place it on a standby status. 210. Code of Crim. P. art. 256.

211. See generally S. DANDo, supra note 1, at 346-47. For a discussion of the competence of courts, see $i d$. at $60-63$.

212. Code of Crim. P. art. 271.

213. Id. art. 273(2). Defense counsel is also notified. Id. art. 273(3).

214. The basic premise is that accused persons are required to be present at all trial proceedings. $I d$. art. 286. Juridical persons are, of course, allowed to appear through an authorized representative. Id. art. 27(1). There are, however, certain exceptions to the basic premise: (1) if the case involves an offense punishable by a fine of 5,000 yen or a minor fine, an accused person is not required to be present, id. art. 284 (although obviously, in this circumstance or any of the circumstances described below, he or she has a right to attend if desired); (2) if the charged offense is punishable by penal detention and the court considers the appearance of an accused person unnecessary for the protection of the accused person's rights, it may permit the accused person to be absent on a day of public trial, but that does not extend to the rendition of judgment, id. art. 285(1); (3) if an offense carries a maximum penalty of imprisonment with or without forced labor for three years or less or a fine of 5,000 yen or less, an accused person is allowed to be absent under the same circumstances as in (2) above, but that does not extend to the first day of public trial and the public trial date at which judgment is rendered, $i d$. art. 285(2); (4) if an accused person, otherwise possessed of the right to attend but in detention, is summoned to appear but refuses without proper grounds to appear and makes it exceptionally difficult for a custodial officer to bring him or her to court, the court can proceed with trial proceedings, including those at which judgment is announced, on that particular 
the opening of public trial proceedings, a public prosecutor must read aloud the accusatory instrument; 215 the presiding judge must then notify the accused of certain rights ${ }^{216}$ and afford both the accused and defense counsel an opportunity to make any statements they desire concerning the case. ${ }^{217}$

One may note in this context the issue of judicial sanctions against abusive prosecutions, which the Supreme Court of Japan has recognized in a limited way. In its Kawamoto judgment, ${ }^{218}$ the Court ruled that abuse of prosecutorial discretion can constitute a bar to prosecution, but that such abuse must be egregious enough to constitute criminal activity. ${ }^{219}$ The abuse of discretion in Kawamoto did not reach that level, but the Court nevertheless refused to exercise its powers of reversal based on incompatibility with justice ${ }^{220}$ to upset the Tokyo High Court judgment ${ }^{221}$ that had dismissed the prosecution as not founded in law.

\section{Counsel}

Article 37(3) of the Constitution provides that "criminally accused persons"(keijihikokunin) at all times have the right to the assistance of competent counsel, which must be provided by the government if the accused are unable personally (mizukara) to obtain it. ${ }^{222}$ The legal dichotomy between suspects and accused persons, discussed earlier, ${ }^{223}$ once again is critical: the constitutional right to counsel in Japan governs only after the

occasion only, id. art. 286(2) (The same provision would govern each occasion on which a qualifying accused person is obstreperous, but a separate determination would be required each time.); (5) accused persons can be ordered to leave the courtroom temporarily during the examination of witnesses against whom they may exert pressures affecting testimony, id. art. 304(2); (6) judgment may be pronounced in the absence of accused persons who leave the court without permission or have been ordered from it by a presiding judge based on disorderly conduct, id. art. 341 ; and (7) judgments in favor of accused persons who are mentally ill can be rendered in their absence, $i d$. art. 314(1) proviso. See generally S. Dando, supra note 1, at 369-70.

215. Code of Crim. P. art. 291(1).

216. The notification extends principally to the right to remain silent and to refuse to answer any questions. Id. art. 291(2). However, under the Rules of Criminal Procedure, the presiding judge also must advise an accused person of the right to make statements that may be used either for or against the accused person. Id. art. 197(1). The presiding judge also has discretion to explain any other protective procedural rights that an accused person appears unable to understand fully. $I d$. art. 197(2).

217. Code of Crim. P. art. 291(2). Japanese courts may order public prosecutors to disclose documents and evidentiary material in their possession, which perhaps is the closest approach to compelled discovery in Japanese practice. See Dando, supra note 43, at 644-45.

218. Japan v. Kawamoto, 34 Keishū 672 (Sup. Ct., 1st P.B., Dec. 17, 1980). See generally George, supra note 36, at 274-76; Upham, Japan v. Kawamoto: Judicial Limits on the State's Power to Indict, 13 LAW IN JAPAN 137 (1980).

219. See Penal CODE art. 194 (abuse of authority in the form of arrest or detention by public service official performing or assisting in the performance of judicial, prosecutorial or police functions).

220. Code of Crim. P. art. 411 (ii) (Seigi ni hansuru).

221. Japan v. Kawamoto, 853 Hanrei Jihō 3 (Tokyo H. Ct., June 24, 1977).

222. A limited right of access by retained counsel to a suspect undergoing investigation while in detention appears to have been acknowledged by the Supreme Court in Sugiyama v. Osaka Metropolitan Prefecture, 32 Minshū 820 (Sup. Ct., 1st P.B., July 10, 1978).

223. See supra notes $91-98,129$ and accompanying text. 
institution of public prosecution. Before that time, the claim to counsel is purely statutory under the Code of Criminal Procedure.

Under the Code, suspects as well as accused persons may select or retain counsel at any time. ${ }^{224}$ Notification of that right must be given at frequent intervals throughout the course of criminal proceedings, ${ }^{225}$ and the Constitution requires that accused persons in detention be afforded opportunities to choose counsel. ${ }^{226}$ Counsel selected while the accused is a suspect continues to be recognized throughout trial proceedings, ${ }^{227}$ but representation must be ascertained separately for successive proceedings. ${ }^{228}$

Suspects who are financially or otherwise unable to retain counsel, or whose legal representatives or designated relatives ${ }^{229}$ fail to do so on their behalf, have no claim to appointment of counsel at public expense. After the institution of public prosecution, however, if accused persons do not have counsel, they can request the court to assign counsel. ${ }^{230}$ Moreover, even if the accused persons are financially able, courts on their own motion may designate counsel for accused persons unrepresented by counsel, ${ }^{231}$ if they are minors, aged seventy years of age or older, deaf or mute, ${ }^{232}$ or of doubtful mental capacity, ${ }^{233}$ or where the court deems designation of counsel necessary for any other reason. ${ }^{234}$ When criminal prosecution is based on serious charges, public trial proceedings cannot be conducted without defense counsel in attendance, ${ }^{235}$ and the presiding judge must appoint

224. Code of CRIM. P. art. 30(1). Legal representatives, curators, spouses, lineal relatives, or siblings of either accused persons or suspects also have an independent right to select counsel, whether or not that is the desire of those on whose behalf counsel is retained. Id. art. 30(2). See generally S. DANDo, supre note 1, at 105-06.

225. See Code of CRIM. P. arts. 76 (notice given appearance on production), 77 (notice given before detention), 203 (notice given following arrest on warrant by judicial police officer), 204 (notice given following arrest on warrant or receipt of custody by public prosecutor), 211 (notice given following emergency arrest), 216 (notice given following flagrant delict arrest), 272 (notice given upon initiation of public prosecution).

226. 1947 Const. arts. $35,37(3)$.

227. Id. art. 32(1).

228. Id. art. 32(2). A court may restrict the number of attorneys representing a suspect, id. art. 35 , but may do so with reference to those representing accused persons only on the basis of special circumstances, $i d$. proviso. The basic number is three unless the court establishes the existence of special circumstances for both suspects, Rules of CrIM. P. art. 27(1), and accused persons, id. art. 26(1). When accused persons are represented by multiple counsel, the court designates one as chief defense counsel. Code of Crim. P. art. 33; Rules of Crim. P. arts. 19-24. Powers of chief defense counsel, deputy chief defense counsel, and associate defense counsel are delineated in Article 25 of the Rules of Criminal Procedure. See S. DAndo, supra note 1, at 106.

229. See supra note 226.

230. Code of Crim. P. art. 36.

231. Id. art. 37. Cf. FED. R. CRIM. P. 44(a) ("[E]very defendant who is unable to obtain counsel shall be entitled to have counsel assigned . . . at every stage of the proceedings . ...").

232. Code of Crim. P. art. 37(iii) (designating in asha as eligible, a term also important under Penal Code Article 40 in determining culpability). See S. Dando, supra note 61 , at $\$ 7.03$ n.1.

233. The terms in Article 37(iv) of the Code of Criminal Procedure are "loss of mind" (shinshin sōshitsu) and "weakness of mind" (shinshin gojaku). These, too, are critical under Article 39 of the Penal Code in determining culpability and should have identical meaning in both contexts. See S. DANDo, supra note $61, \S 7.03(1)$.

234. Code of Crim. P. art. 37(v).

235. Id. art. 289(1) (applicable to offenses punishable by death or imprisonment with or without forced labor for life or a maximum term exceeding three years). 
counsel if the accused person is unrepresented ${ }^{236}$ or counsel fails to appear. ${ }^{237}$ Counsel costs ultimately are met by the government for financially unable accused persons. ${ }^{238}$

Because Article 37(3) of the Constitution requires "competent counsel," defense counsel must be admitted to practice under the Lawyers Law. ${ }^{239}$ The powers of counsel are delineated in the Code of Criminal Procedure ${ }^{240}$ and appear to be ample from the standpoint of forensic activities to protect the rights and claims of accused persons. However, there is one major point of controversy: the circumstances of counsel interviews with suspects or accused persons in detention. The basic premise is that counsel or attorneys who will become defense counsel can interview their clients without custodial personnel present and may deliver and receive documents or other matter without restriction. ${ }^{241}$ However, prosecutors and judicial police officials are allowed to designate the times and places of interviews with, and delivery of items to and from, suspects if these limits on interviews and deliveries are necessary to the investigation and do not improperly limit defense preparations. ${ }^{242}$ The defense bar has asserted that police and prosecutors abuse the power of general designation by severely restricting the dates, hours, frequency, and duration of visits and by requiring attorneys to obtain permits from the public prosecutor's offices according to inconvenient administrative procedures. ${ }^{243}$ Once more, the contention is that the Civil and

236. Id. art. $289(2)$.

237. Id. art. 290.

238. Assigned counsel have the right to demand traveling expenses, per diem, lodging expenses and a fee, id. art. 38(2); Criminal Costs Law art. 7; Temporary Law Concerning Criminal Costs art. 3, all of which are included as costs of the prosecution, Criminal Costs Law art. 1. However, these costs are not to be imposed on an accused person financially unable to pay them. Code of Crim. P. art. 181 (1) proviso. If they have been imposed, an accused person can request that enforcement be remitted wholly or in part, based on financial inability. Id. art. 500. On that basis, the Supreme Court held that the provisions of the Criminal Costs Law were not contrary to Article 37(3) of the 1947 Constitution. Japan v. Sudo, 4 Keishū 966 (Sup. Ct., G.B., June 7, 1950) (before the enactment of the proviso to Code of Criminal Procedure Article 181).

239. Code of CRIM. P. art. 31(1). In summary, family, and district courts, persons not qualified as practicing attorneys may be selected with the permission of the court, but these laypersons may serve only as supernumerary counsel in district courts, where one defense counsel must be a practicing attorney. Id. art. 31(2). Accused persons also can designate a legal representative, curator, spouse, lineal relative, or sibling as an assistant (hosanin). Id. art. 42(1). After notifying the court of the appointment for each trial instance, id. art. 42(2), the assistant can perform all procedural acts that an accused person can as long as this does not violate the expressed wishes of the latter or run counter to legal requirements, id. art. 42(3). See S. DANDo, supra note 1, at 110-11.

240. Code of Crim. P. arts. 31 (1) (selection of counsel), 38(1) (assigned counsel).

241. Id. art. 39(1). The delivery of items to and from suspects is subject to reasonable restrictions in the interests of forestalling escape, the destruction or alteration of evidence, or the introduction of material that may interfere with institutional security. Id. art. 39(2). See S. Dando, supra note 1, at 109.

242. Cone of Crim. P. art. 39(3) (public prosecutors, public prosecutor's assistant officers, judicial police officers, and constables are accorded the power of designation). See S. Dando, supra note 1, at 109-10; Cleary, supra note 70, at $141-43$ (discussing civil litigation in which attorney failed to obtain a civil recovery from the government for asserted unlawful interference with client interviews).

243. See, e.g., JCLU RePort, supra note 202, at 56-61; Saito, supra note 150, at 58-59; Tamiya, On the Designation of Communication with Counsel, 4 LAw IN JAPAN 87 (1970). A related alleged abuse is 
Political Rights Covenant ${ }^{244}$ forbids a continuation of these restrictions derived from Article 39(3) of the Code. However, the prospects of Supreme Court adoption of such a premise appear most dim, as the JCLU appears to recognize in calling for legislative attention to the problem. ${ }^{245}$

\section{E. Multiple Convictions for the Same Offense}

Article 39 of the Constitution states that no person shall be held criminally culpable more than once for the same matter (ichijifusairi). ${ }^{246}$ The Japanese concept is derived from the Roman law tradition, ${ }^{247}$ as is demonstrated by the fact that the protections of Article 39 do not attach until all appeals in regular course have been completed or forgone. Hence, the Supreme Court of Japan ruled $^{248}$ that Article 351(1) of the Code, which allows both a convicted accused person or a public prosecutor to lodge an appeal against a judgment, is constitutional; the Court indicated expressly that Article 39 does not incorporate Anglo-American doctrines. 249

If a repeated prosecution should be initiated in contravention of Article 39 , the remedy is a judgment of acquittal on procedural grounds. ${ }^{250}$

arrest on different charges (bekken taiho) as a device to obtain an additional period of twenty-three or twenty-eight days of detention. See supra notes 70, 150; JCLU REPORT, supra note 202, at 60 n.".

244. Supra note 203, art. 14(3) (accused persons have the minimum guarantee "in full equality:

(b) To have adequate time and facilities for the preparation of [their] defence and to communicate with counsel of [their] own choosing ....").

245. See JCLU REPORT, supra note 202, at 62-63.

246. The cumulative imposition of a tax deficiency penalty and a penal fine does not violate the provision. Japan v. Kotobukiya K.K., 12 Minshū 938 (Sup. Ct., G.B., April 30, 1958). Cf. United States v. Halper, 490 U.S. 435 (1989) (civil penalty cumulating to over 300 times the actual cost imposed through fraud on government was a criminal penalty within the meaning of double jeopardy).

247. Although the term ichijifusain is usually translated as "double jeopardy," the concept is closer to the Roman law concept of non bis in idem than to Anglo-American double jeopardy, so that the latter term ought not be used for ichijifusairi lest it create confusion on the part of uninitiated persons.

248. Japan v. Ishizaki, 4 Keishū 1805 (Sup. Ct., G.B., Sept. 27, 1950), translated in CourT AND Constitution in Japan: Selected Supreme Court Decisions, 1948-60, at 219 (J. Maki ed. 1964) [hereinafter J. MAKI].

249. Under the United States Constitution's fifth amendment double jeopardy clause, jeopardy attaches in jury cases when the jury is empaneled and sworn, Crist v. Bretz, 437 U.S. 28 (1978), and in bench trials when the first prosecution witness is sworn, Serfass v. United States, 420 U.S. 377,388 (1975) (the point at which a court begins to "receive evidence"). United States $v$. Martin Linen Supply Co., 430 U.S. 564, 569 (1977). If authorized by statute, appeal by the prosecution is possible, before jeopardy attaches, e.g., 18 U.S.C. $\$ 3731$ (1982), a practice approved in Serfass, or when the prosecution is challenging sentences imposed unlawfully, United States v. DiFrancesco, 449 U.S. 117 (1980); see also 18 U.S.C.A. $\$ 3742$ (b) (West Supp. 1989) (prosecution appeals based on downward departures from federal sentencing guidelines), or when the prosecution is appealing to a jurisdiction's highest court after a defendant has prevailed in an intermediate appellate court. No counterpart concerns are evident in the Japanese or other Roman law-derived systems because of the deferred point at which the non bis in idem doctrine ripens.

250. Code of Crim. P. art. 337(i). See S. Dando, supra note 1, at 240. 


\section{F. Speedy Trial}

The Constitution guarantees a speedy trial. ${ }^{251}$ However, as in the United States, ${ }^{252}$ the constitutional barrier to protracted trial does not rise swiftly. ${ }^{253}$ With the exception of trials that can be completed in two days or less and that are to be conducted without recess, courts are simply admonished to try to carry on continuous trials. ${ }^{254}$ Despite the admonition, first-instance trial proceedings can extend for months or years before the entry of judgment. ${ }^{255}$ Protracted criminal proceedings may not matter much to accused persons who are not detained, but one may question whether that is so if they are held in detention for significant periods. Nevertheless, the amount of concern expressed over the matter seems modest.

\section{G. Public Trial}

Under the Constitution, accused persons are accorded a right to a public trial;256 trials are to be conducted and judgments pronounced in open court, ${ }^{257}$ subject to quite limited exceptions. ${ }^{258}$ The right of publicity also extends to protocols of trial, which are viewed as public records. ${ }^{259}$ The latter

251. 1947 Const. art. 37(1) (jinsoku na saiban).

252. See Barker v. Wingo, 407 U.S. 514 (1972). A similar balancing approach is evident in Japan v. Nakasu, 29 Keishū 393 (Sup. Ct., 1st P.B., Aug. 6, 1975).

253. In Japan v. Boku (Paik), 26 Keishū 631 (Sup. Ct., G.B., Dec. 20, 1972), translated in H. TANAKA, supra note 25 , at 478 , a sixteen-year suspension of trial proceedings forestalled resumption of trial. If delay is viewed as not having affected the propriety of the judgment in a case, there will be no reversal. See Japan v. Nagashima, 2 Keishū 1853 (Sup. Ct., G.B., Dec. 22, 1948), translated in J. MAKI, supra note 248, at 207. If the constitutional guarantee is violated, an accused may resort to extraordinay relief procedures. See 26 Keishū 631. See generally Dando, supra note 43, at 641-42; Suzuki, Speedy Administration of Criminal Justice: The Right of the Accused and the Interest of Society, 15 UNAFEI Resource Material Series 91, 92-93 (1978).

254. “As far as possible" (dekiru kagiri). Rules of Crim. P. art. 179(2).

255. For example, in $1986,70.7 \%$ of the 63,718 district court cases were disposed of within three months, an additional $21.8 \%$ in six months or less, and $5.3 \%$ more within a year. In summary courts, $97.8 \%$ of 15,398 cases were disposed of within a year. JAPAN Ministry of Justice ReSEARCH AND Training Institute, Summary of White Paper on Crime 102 (1988).

256. 1947 Const. art. $37(1)$.

257. Id. art. 82(1) (kökai hotei). Reopening of procedure (saishin) proceedings are not within Article 82(1). Japan v. Ueno, 12 Keishū 1683 (Sup. Ct., Ist P.B., May 27, 1958).

258. If trial proceedings do not involve political offenses or offenses involving the press (shuppan) or relate to constitutional rights under Chapter III of the 1947 Constitution, they can be conducted privately, as long as a court unanimously determines that opening the proceedings to the public will endanger public order or morals. Id art. 82(2). Trial proceedings relating to the exempted classes of cases must always be open to the public, id. proviso, but it should be noted that this does not apply to the pronouncement of judgment. See S. Dando, supra note 1, at 360-61.

Before closing trial proceedings to the public, a court must state the reasons for closure. Court Law art. 70. Spectators must be readmitted when judgment is pronounced. Id.

259. CODE OF CRIM. P. art. 53(1). However, the provision is inapplicable if the process of examination interferes with the preservation of trial records or the functions of a court or public prosecutor's office. Id . Records relating to closed trial proceedings, see supra note 258, are unavailable to persons other than those directly interested in the case or to others who have obtained special permission from the custodian of those records. CODE OF CRIM. P. art. 53(2). Preservation of records and charges for inspection are covered by separate legislation. Id. art. 53(4); Law for 
corresponds generally to the position taken by the United States Supreme Court. ${ }^{260}$

\section{H. Impartial Tribunal}

To be constitutional, a trial also must be held before an impartial tribunal.261 Impartiality of judges and courts conducting specific trials is promoted, of course, by the maintenance of the independence of the judiciary. ${ }^{262}$ In individual proceedings, however, it is advanced through the system of recusal by judges who recognize their potential disqualification ${ }^{263}$ or by challenges by either side, ${ }^{264}$ the grounds for which are set forth in the Code. ${ }^{265}$ Rather detailed provisions govern the processing of challenges. ${ }^{266}$

Japan does not currently utilize a jury system or any other form of lay participation in trial proceedings, such as is encountered in some Roman lawderived systems. ${ }^{267}$ For a time, Japan did in fact use a jury system patterned significantly on the Anglo-American institution, ${ }^{268}$ but the Jury Law was suspended in operation in $1943^{269}$ and has not been revived to date. ${ }^{270}$

Implementation of the Code of Criminal Procedure art. 11. See generally S. Dando, supra note 1, at 361 .

In Repeta v. Japan, 1299 Hanrei Jiho 41 (Sup. Ct., G.B., Mar. 8, 1989), the Supreme Court gave at least qualified recognition to the right of individuals (in that instance, an American attorney) to take notes in court about formal proceedings.

260. See Press-Enterprise Co. v. Superior Court, 478 U.S. 1 (1986) (press access to preliminary examination records).

261. 1947 ConST. art. 37(1)

262. Id. art. 76(3) ("all judges shall be independent in the exercise of their conscience and shall be bound only by this Constitution and the laws"). See S. DANDo, supra note 1, at 49-50.

263. Code of Crim. P. art. 23(2); Rules of Crim. P. art. 13. See S. Dando, supra note 1, at 60.

264. Code of Crim. P. arts. 21-25. Such challenges also may be made to court clerks on substantially equivalent grounds. Id. art. 26. See S. Dando, supra note 1, at 60 . The time limitations in Code of Criminal Procedure Article 22, governing challenges, do not violate the 1947 Constitution Article 37(1). Japan v. Kobayashi, 18 Keishū 107 (Sup. Ct., G.B., Mar. 12, 1964).

265. Code of CRIM. P. art. 20. The grounds are: (1) the judge is the victim; (2) the judge is or was a relative of the accused person or victim; (3) the judge is a legal representative, supervisor of guardianship, or curator of the accused person or victim; (4) the judge has acted as a witness or expert witness in the case; (5) the judge has acted as a representative, counsel, or assistant of the accused person; (6) the judge has exercised the functions of a public prosecutor or judicial police officer in the case; or (7) the judge has participated in any of certain specified activities in the preliminary phases of the case, other than as a requisitioned judge. The latter ground is not a ground for challenging a court clerk, however. Id. art. 26(1).

266. See generally S. DANDo, supra note 1, at 59-60.

267. See J. Langbein, Comparative Criminal Procedure: Germany 61-62, 63 (1977); A. von Mehren \& J. Gordley, Civil Law System 99 n.12 (2d ed. 1977) (French law); Kock, Introduction, in 7 American Series of foreign Penal Codes, French Criminal Procedure Code 8-9, 10 (G. Kock trans. 1964); Schmidt, Introduction, in 10 American Series of Foreign Penal Codes, German Criminal Procedure Code 4-5, 8, 17 (H. Neibler trans. 1965).

268. Baishinhō (Jury Law), Law No. 50, 1923 (in force from Oct. 1, 1928). See generally S. Dando, supra note 1, at 18; S. FujII, supra note 24, at 316-17; M. MiYaKe, OutLine of the JaPANESE Judiciary 7-8 (rev. 2d ed. 1935).

269. Baishinbōshihō (Law Suspending the Jury Law), Law No. 88, 1943. See H. Tanaka, supra note 25 , at $482-91$.

270. Based on the author's conversations with representatives of Nichibenren (Japanese Federation of Bar Associations), some members of that organization are exploring recommendations that the jury system be revived. 


\section{The Right to Have Witnesses Summoned}

Under Article 37(2) of the Constitution, criminally accused persons have the right to demand that witnesses be summoned for their benefit, according to compulsory procedures and at public expense. ${ }^{271}$ Under the Japanese practice, a public prosecutor, accused person, or defense counsel wishing to have witnesses examined submits a request to the trial court. ${ }^{272}$ Although a court has the power to examine any person as a witness, ${ }^{273}$ it also has discretion whether to grant all defense or prosecution requests that witnesses be summoned. If the court believes that witnesses desired by either party will offer irrelevant or cumulative data, it can refuse to summon them without violating the guarantee of Article 37(2). ${ }^{274}$ If summoned witnesses fail to appear, either a renewed summons or a warrant of production is issued to compel their attendance. ${ }^{275}$ It appears to be a matter of debate whether the expenses generated for the government by the processes of summoning and examining defense witnesses can be imposed on convicted defendants as costs of trial, in light of the constitutional requirement that witnesses be summoned at public expense. ${ }^{276}$

\section{J. Presence and Examination of Witnesses}

As discussed above, ${ }^{277}$ accused persons have a right to be present at trial, although that right is expressed in the Code of Criminal Procedure and not the Constitution. However, the Constitution guarantees accused persons an opportunity to examine all witnesses, ${ }^{278}$ which at least implies a right to be present. ${ }^{279}$ The right of examination is not limited to witnesses whom accused persons have requested to be summoned to give testimony, but

271. Although the usual translation is "compulsory process," the author believes the paraphrase in the main text of the phrase, "köhei de jiko no tame ni kyōseiteki tetsuzuki ni yori shōnin o motomeru kenri o yusuru," is closer in meaning to the original and less misleading, granted the different procedures and degree of judicial involvement in the Japanese and United States systems. Compare CoDE OF CRIM. P. arts. 143,150 to 153 (2) (summons and production of witnesses) with FED. R. CRIM. P. 17 (federal subpoena practice).

272. Code of Crim. P. art. 298(1). For the procedural details, see Rules of Crim. P. arts. 188193. Discovery of the names and addresses of witnesses whose examination has been requested is required. Code of Crim. P. art. 299(1).

273. Code of Crim. P. art. 143.

274. See S. Dando, supra note 1 , at 282 (citing precedent in accord).

275. Code of Crim. P. arts. 152 to 153(2). Witnesses who fail to respond without good reason may also be punished by a fine or penal detention, id. art. 151 , or subjected to a nonpenal fine and liability for expenses generated by their nonappearance, id. art. 150.

276. See S. DANDo, supra note 1, at 299 n.9. Impecunious convicted persons can request a total or partial remission of costs imposed upon conviction, CoDE of Crim. P. arts. 181(1), 500, but the constitutional issue seems inescapable if convicted accused persons cannot invoke the remission option.

277. See supra note 214.

278. 1947 Consr. art. 37(2) ("Subete no shōnin ni taishite shinmon suru kikai o jübun ataerare . . kenri o yüsuru").

279. In concept, the right to be present as a matter of U.S. constitutional law appears to be based in due process of law to the extent that fairness of trial is the focus, but is either part of or derived from the sixth amendment right of confrontation to the extent that opportunities to cross-examine prosecution witnesses are contemplated. See Kentucky v. Stincer, 482 U.S. 730 (1987). 
instead extends to all witnesses summoned on a day of public trial. ${ }^{280}$ The Code of Criminal Procedure was conceived of as initiating an adversarial system of trial proceedings, during which direct and cross-examination of witnesses physically present in court would be of crucial importance, ${ }^{281}$ to replace the earlier system in which documentary data were all-important. ${ }^{282}$ Article $37(2)$ of the Constitution derives its primary significance from the altered character of criminal proceedings. Nevertheless, the Code of Criminal Procedure allows documents and statements to be used as evidence if a public prosecutor and an accused person consent, ${ }^{283}$ and allows stipulations to the contents of documents or substance of testimony that witnesses might give if they were to attend. ${ }^{284}$ There are indications that documentary proof is gradually replacing live witness testimony in many criminal cases; if that trend becomes predominant, then the practical significance of the constitutional provision will diminish.

\section{K. Right of Silence}

Article 38(1) of the Constitution protects all persons, whether suspects or accused persons, from being compelled to testify against themselves. ${ }^{285}$ Although there are modest differences in detail, the Japanese right of silence and the American constitutional privilege against self-incrimination are closely congruent. ${ }^{286}$ The constitutional protection is implemented in the Code of Civil Procedure 287 and the Code of Criminal Procedure. ${ }^{288}$ Accordingly, most issues tend to be resolved in form as matters of statutory interpretation and application rather than as constitutional questions. If there

280. Code of Crim. P. art. 304(2); S. Dando, supra note 1, at 281-82. When documents or demonstrative evidentiary data are offered, they are read or tendered at a day of public trial, CoDE of CRIM. P. arts. 305 to $307(2)$, and the court must afford an appropriate opportunity to a public prosecutor, accused person, and defense counsel to challenge the probative value, id. art. 308. See generally Kim, Criminal Trial in Japan: The Accused's Right to Confrontation and Cross-Examination of Witnesses, in Festschrift for Dr. Chin Kim: Selected Problems in Contemporary Comparative LAW 536 (1987).

281. See A. OPpler, supra note 27 , at 140-44.

282. See supra notes 38-42 and accompanying text.

283. Code of Crim. P. art. 326(1). Accused persons who are absent under circumstances allowing trial procedures to be conducted in their absence, see supra note 214 , are deemed to give consent, provided no representative or defense counsel appears for them to give or withhold consent. Code of Crim. P. art. 326(2).

284. Id. art. 327.

285. "Nambito mo jiko ni furieki no kyojutsu o kyōyū sarenai." 1947 Const. art. 38(1).

286. See generally Armstrong, supra note 14, at 194-95; George, "Right of Silence" in Japanese Law, 43 Wash. L. Rev. 1147 (1968), reprinted in The Japan Constitution: Its First Twenty Years, 1947-67, at 257 (D. Henderson ed. 1968) [hereinafter George, Right of Silence]. See also S. Dando, supra note 1, at 280-81. In more recent decisions, the Supreme Court has held that neither information required on customs forms, Japan v. Kawasaki, 33 Keishū 301 (Sup. Ct., 3rd P.B., May 29, 1979), and in the course of administrative inquiries relating to possibly delinquent taxes, Japan v. Hashimoto, 38 Keishū 2037 (Sup. Ct., 3rd P.B., March 27, 1984), is compelled within the meaning of Article 37(i) of the 1947 Constitution.

287. Code of Civil P. art. 280 (according any witness a right to decline to answer incriminating questions).

288. Code of Crim. P. arts. 146 (right of witnesses to refuse to answer incriminating questions), 311 (1) (right of accused person to remain silent at all times or to refuse to answer any question in the course of (rial). 
is a deficiency in the legislative system, at least from the government's standpoint, it lies in the lack of legislative mechanisms to confer immunity on witnesses so that they may be compelled to testify. ${ }^{289}$ Japanese criminal procedural law also incorporates a number of evidentiary privileges that are exclusively statutory and not constitutional in nature. ${ }^{290}$

\section{Adjudication}

The only express constitutional requirement affecting the rendering of adjudications is that they be done publicly. ${ }^{291}$ Accordingly, the details and alternative forms of adjudications in criminal cases are set by statute. ${ }^{292}$ The standard expectation is that judgment will not be rendered until an accused person has been afforded an opportunity to submit a personal statement, but that limitation does not pertain if an accused person has left court without permission or has been ordered by the presiding judge to leave as a means of maintaining order in court. ${ }^{293}$

The Constitution is silent on the allocation and strength of the burden of persuasion in criminal matters. ${ }^{294}$ Under the Code of Criminal Procedure, ${ }^{295}$ if a public prosecutor fails to establish by sufficient proof that an accused person committed a charged offense, the court must enter a judgment of acquittal. Although Japanese judges follow the Roman law tradition of free evaluation of evidence, ${ }^{296}$ that tradition in itself bears only on the judges' independence in function. However, the judges also follow the principle of in dubio pro reo, that is, the rule that all questions of doubt are to be resolved in favor of an accused person. ${ }^{297}$ Although a precise comparative evaluation of in dubio pro reo and "proof beyond a reasonable doubt" is probably impossible, the author's qualitative belief is that innocent accused persons are somewhat more strongly protected against unjust convictions in Japan than under the American system of trial by jury.

289. See George, Right of Silence, supra note 286, at 1165-66. See also 18 U.S.C. \$§ 6001-6005 (1982) (federal immunity legislation); N.Y. CrIm. Proc. LAw $\$ \S 50.10-30$ (immunity other than for grand jury witness), 190.40 (grand jury witness) (McKinney 1982).

290. See Code of Crim. P. arts. 144-45 (official secrets), 147 (incrimination of spouses, relatives, and others in designated close personal relationships to witnesses), 149 (designated professionals possessing confidential information). S. DANDo, supra note 1, at 279-80.

291. 1947 Const. art. 81(1); CODE OF CRIM. P. art. 342. See supra notes 256-60 and accompanying text.

292. Code of Crim. P. arts. 329-350. See S. Dando, supra note 1, at 383-86.

293. Code of Crim. P. art. 351.

294. American constitutional doctrine has been developed under the due process clauses. See, e.g., Hicks v. Feiock, 485 U.S. 624 (1988) (contrasting civil and criminal contempt proceedings); Martin v. Ohio, 480 U.S. 228 (1987) (allocation of burdens of establishing affirmative defenses); In re Winship, 397 U.S. 358, 365-66 (1970) (basic doctrine). The Supreme Court of Japan might reach the same position if it utilized Article 31 of the 1947 Constitution as a due process clause, but apparently it has not done so thus far.

295. Code of Crim. P. art. 336. See S. Dando, supra note 1, at 191-92.

296. Code of Crim. P. art. 318 (jiyūna shinshō). See S. Dando, supra note 1, at 174, 203-04.

297. See S. Dando, supra note 1 , at 191. 
One might note, incidentally, that under the system for resolving divisions of opinion in collegiate courts under the Court Law298 when there is no majority view, the opinion least favorable to an accused person is joined with that next least favorable so that a majority is reached, ${ }^{299}$ at which point the opinion of the two most favorable to the accused person becomes the judgment of the court.

One additional point is worth mentioning in this context. Article 38(3) of the Constitution prohibits the conviction or punishment of any person if the sole proof against that person is his or her own adverse confession. Although this might be viewed as accomplishing no more than the so-called corpus delicti rule in Anglo-American criminal procedure, ${ }^{300}$ applicable only to proof of extrajudicial confessions, and though the Supreme Court of Japan ruled in an early postwar case that Article 38(3) does not govern confessions in open court, ${ }^{301}$ the Code of Criminal Procedure ${ }^{302}$ bars convictions based on an admission of guilt in open court. Accordingly, there is no room for a guiltyplea practice in Japan corresponding to that which is used sweepingly in the United States. ${ }^{303}$

Nevertheless, one may note two aspects of Japanese criminal procedure that tend to accomplish somewhat similar results to guilty pleas. One is a system of summary proceedings on minor charges in summary courts. These proceedings can be precipitated by a public prosecutor's demand for a summary order, which is legally equivalent to a judgment of guilt and which can be entered if the accused person does not demand a formal trial within a specified time after receiving notification of a summary order. ${ }^{304}$ By not contesting a summary order, accused persons agree to the entry of judgment without formal reception and evaluation of evidence.

The second method is simplified trial proceedings. ${ }^{305}$ After an accused person has appeared at the opening of public trial, heard a reading of the accusatory instrument by a public prosecutor, ${ }^{306}$ and been notified by the presiding judge of the right to make any statement concerning the case,$^{307}$ the

298. 1947 Const. art. 77. See S. Dando, supra note 1, at 231.

299. A collegial court for the trial of serious criminal cases always consists of three judges. Court Law art. 26(2)(ii), (3). See S. DANDo, supra note 1, at 54-55. However, trial proceedings do not become ineffective because it is discovered toward the conclusion of trial proceedings that they should have been conducted by a collegial court rather than by a single judge. Code OF CRIM. P. art. 316.

300. See S. Dando, supra note 1, at 205-06.

301. Japan v. Sato, 2 Keishū 1012 (Sup. Ct., G.B., July 29, 1948). A confession of someone jointly charged does suffice. Japan v. Yajima, 12 Keishū 1718 (Sup. Ct., G.B., May 28, 1958). On police efforts to obtain potentially corroborative evidence, see Cleary, supra note 70 , at 128-29.

302. Code of CRIM. P. art. 319(3).

303. See Fed. R. Crim. P. 11.

304. See Code of Crim. P. arts. 461-470. Applications for formal trial must be submitted within 14 days after receiving a notification; if no application is submitted or an application is withdrawn or dismissed, a summary order has the same effect as a formal judgment. Id. art. 470. See S. Dando, supra note 1, at 494-99. A similar special system governs minor traffic cases. See id. at 499-504.

305. See S. Dando, supra note 1 , at 377-79.

306. Code of Crim. P. art. 291(1).

307. Id. art. 291(2). 
accused person is allowed to acknowledge guilt of one or more of the offenses set forth in the accusatory instrument ${ }^{\mathbf{3 0 8}}$ if the charges are not overly serious in character. ${ }^{309}$ If, after hearing the opinions on the matter of a public prosecutor, accused person, and defense counsel, the court rules that simplified trial proceedings will take place, the usual opening statement by a public prosecutor is omitted, ${ }^{310}$ as is a determination of the scope, order, and method of proof. ${ }^{311}$ The usual formalities relating to the examination of evidence are dispensed with, ${ }^{312}$ and the court may examine evidence on whatever basis it wishes. ${ }^{313}$ Thereafter, the procedures following the receipt of evidentiary data, particularly closing statements and an adjudication, are standard. ${ }^{314}$ Once more, direct comparisons are difficult, but the author's subjective reaction is that simplified trial proceedings do not differ significantly from guilty-plea procedures conducted carefully under Rule 11 of the Federal Rules of Criminal Procedure or a state counterpart, although the guilty-plea procedures in the United States are more widely available than simplified trial proceedings in Japan. ${ }^{315}$

\section{Appeal}

As in U.S. constitutional doctrine, ${ }^{316}$ the Japanese Constitution makes no specific reference to appeals. However, the Code of Criminal Procedure contains elaborate provisions governing a number of procedures for appellate review in criminal cases, ${ }^{317}$ so that there has been no need to consider whether an expanded interpretation of Article 31 would embrace at least one instance of review on behalf of accused persons who have been convicted.

308. Id. art. 291(2).

309. The provision is inapplicable crimes punishable by death or imprisonment with or without forced labor for life or a minimum term exceeding one year. Id. proviso.

310. Id. art. 296.

311. Id. art. 297.

312. Id. arts. $300-302,304$.

313. Id. art. $307(2)$.

314. If an order for simplified trial proceedings should be rescinded, regular trial procedures should begin anew, unless a public prosecutor and the accused person or defense counsel decide not to object to entry of an adjudication on the basis of simplified trial proceedings occurring before rescission. Id. art. $315(2)$.

315. Rule 11 (a) of the Federal Rules of Criminal Procedure contains no limitations on the gravity of cases in which guilty and nolo contendere pleas can be tendered. On the limitations set by Japan Code of Criminal Procedure art. 29(2) proviso, see supra note 309.

316. See, e.g., Jones v. Barnes, 463 U.S. 745 (1983); McKane v. Durston, 153 U.S. 684 (1894) (dictum).

317. Code of Crim. P. arts. 35I-434. See S. Dando, supra note 1, at 408-48. There are also two forms of extraordinary review following the conclusion of regular appeals: (1) reopening of proceedings (saishin), Code of Crim. P. arts. 435-453; see S. Dando, supra note 1, at 480-86; and (2) extraordinary jokoku appeal, Code of CrIm. P. arts. 454-60; see S. DANDo, supra note 1, at 486-89. The Supreme Court took a relatively liberal view of the coverage of Article 435(vi) of the Code of Criminal Procedure, e.g., Japan v. Shiratori, 29 Keishū 177 (Sup. Ct., Ist P.B., May 20, 1975), discussed in Dando, supra note 43, at 645; Japan v. Taniguchi, 30 Keishũ 1673 (Sup. Ct., 1st P.B., Oct. 12, 1976), which has resulted in an increase in the frequency with which lower courts have granted saishin relief. See Dando, supra note 43, at 645. 
VI

\section{Conclusion}

The foregoing summary of the procedural status of, and constitutional and statutory safeguards for, suspects and accused persons in Japan should demonstrate that the protection of human rights there has reached a highly advanced and sophisticated level. As under any system of procedural law, constitutional and statutory provisions that purport to protect individuals can be abused. However, the combination of a structure of government and procedure that guarantees independence of prosecutorial ${ }^{318}$ and judicial ${ }^{319}$ functions against political and community influences, and the high standards of professionalism manifested in both branches of the criminal justice system $^{320}$ has limited instances of established or documented abuses to generally tolerable levels. Modest amendments to the Code of Criminal Procedure should eliminate most or all of those that have been identified. ${ }^{321}$ Consequently, the effective constitutional protection of the human rights of the criminally accused may justly be viewed as one of the paramount accomplishments of Japan's modern constitutional era.

318. See George, supra note 36 , at 266-69.

319. See George, supra note 43, at 814-16.

320. See George, supra note 36, at 264-65; George, supra note 43, at 812-14.

321. One might note the extremely limited list of concerns incorporated in the final report of the Commission on the Constitution. See Commission, supra note 27, at 281-83, 384-85. 
